\title{
THIRTY YEARS OF CURRENCY CRISES IN ARGENTINA: EXTERNAL SHOCKS OR DOMESTIC FRAGILITY?
}

\author{
Graciela Kaminsky \\ Amine Mati \\ Nada Choueiri \\ Working Paper 15478 \\ http://www.nber.org/papers/w15478
NATIONAL BUREAU OF ECONOMIC RESEARCH
1050 Massachusetts Avenue
Cambridge, MA 02138 \\ November 2009
}

This paper was written for the Economía 18th Panel Meeting- LACEA, IMPA - Rio de Janeiro, Brazil, November 21, 2008. We thank Gastón Gelos, Roberto Rigobon, Federico Sturzenegger, Carlos Winograd, and participants at the Economia Meeting for helpful comments. The views expressed herein are those of the authors and should not be attributed to the IMF, its Executive Board, its management, or the National Bureau of Economic Research.

NBER working papers are circulated for discussion and comment purposes. They have not been peerreviewed or been subject to the review by the NBER Board of Directors that accompanies official NBER publications.

(C) 2009 by Graciela Kaminsky, Amine Mati, and Nada Choueiri. All rights reserved. Short sections of text, not to exceed two paragraphs, may be quoted without explicit permission provided that full credit, including $(\subset$ notice, is given to the source. 
Thirty Years of Currency Crises in Argentina: External Shocks or Domestic Fragility?

Graciela Kaminsky, Amine Mati, and Nada Choueiri

NBER Working Paper No. 15478

November 2009

JEL No. F3,F30,F32,F34

\section{ABSTRACT}

This paper examines Argentina's currency crises from 1970 to 2001, with particular attention to the role of domestic and external factors. Using VAR estimations, we find that deteriorating domestic fundamentals matter. For example, at the core of the late 1980s crises was excessively loose monetary policy while a sharp output contration triggered the collapse of the currency board in January 2002. In contrast, adverse external shocks were at the heart of the 1995 crisis, with spillovers from the Mexican crisis and high world interest rates being key sources of financial distress.

Graciela Kaminsky

Department of Economics

George Washington University

Washington, DC 20052

and NBER

graciela@gwu.edu

Nada Choueiri

International Monetary Fund

700 19th Street, N.W.

Washington, D.C. 20431

nchoueiri@imf.org

\author{
Amine Mati \\ International Monetary Fund \\ 700 19th Street, N.W. \\ Washington, D.C. 20431 \\ amati@imf.org
}




\section{Introduction}

Argentina has had an active presence in international capital markets since its independence in the early $19^{\text {th }}$ century. Participation has been quite volatile though. In the early 1800s, in the midst of the lending boom fueled by the end of the Napoleonic wars, Argentina as well as many countries in Latin America were able to issue bonds in London to finance their wars of independence and the civil wars that followed. This lending boom ended in the summer of 1825 when the Bank of England raised the discount rate to stop the drain in reserves. The tightening of liquidity was followed by stock market crashes, banking problems, and recessions in England and Continental Europe. Within months, the crisis also spread to Latin America. Argentina defaulted in 1827 in the midst of what is known as the first Latin American Debt Crisis, only resuming payments in 1857.

Similar international capital flow booms to emerging markets occurred in 1867-1872, 1880-1890, 1893-1913, and 1920-1929 fueled by an easing monetary stance in the financial centers of those times and by the financial needs of railway expansion, urbanization, and development of the banking sector of countries in the periphery. While Argentina participated heavily in all these capital flow bonanzas, its participation was quite volatile with financial crises often following booms. ${ }^{1}$

In the aftermath of the crisis of the 1930s, international capital markets all but disappeared and Argentina was unable to borrow again until the 1970s. The period from the mid-1970s to 2002 was as tumultuous as that of the earlier era and characterized by booms and busts in international capital flows, crises, and failed stabilization programs. During this period, Argentina had eight currency crises, four banking crises, and two sovereign defaults. Many argued that domestic fragilities were at the heart of these crises. ${ }^{2}$ Others blamed erratic international capital markets by pointing out the lending boom of the late 1970s that ended with defaults across all Latin American countries or the lending cycle of the 1990s that triggered banking and currency crises in the most active participants in international capital markets, such

\footnotetext{
${ }^{1}$ For example, the boom of the 1880s ended with banking and currency crises as well as a sovereign default, while the end of the capital inflow episode of the 1920s led to Argentina's abandonment of the gold standard. See, Kaminsky (2009) for an analysis of Latin America's participation in international capital markets from independence to the Great Depression.

${ }^{2}$ See, for example, Mussa (2002) and Perry and Serven (2002)
} 
as Argentina, Brazil, Colombia, Mexico, Peru, and Venezuela. ${ }^{3}$ This important debate is still unsettled. Now, in the midst of the worst international financial crisis since the great depression, untangling the roots of financial distress becomes crucial. This is the question we plan to examine in this paper.

We focus on Argentina's currency crises of the last thirty years. We cast our net wide and examine the role of three external shocks and four sources of domestic vulnerability on currency turmoil. Our selection of external shocks centers on the role of the easing/tightening of monetary policy in the world financial centers, financial contagion and overall "international investors' sentiment” about emerging markets, and real exchange rate misalignments caused by currency depreciations in Argentina's major trading partners. With respect to domestic vulnerabilities, we focus on the boom-bust cycle of domestic credit and monetary policy, fiscal problems, shocks to economic activity, and increases in households' risk aversion triggered by spells of hyperinflation, controls on foreign exchange transactions, cycles of controls on prices and wages, and bank deposit confiscations that have plagued Argentina's recent history. To capture the onset of the crises and track the buildup of fragility during fixed exchange rate regimes, we look at the evolution of foreign exchange reserves of the central bank as a proportion of domestic credit. For short periods of time in the early 1970s and late 1980s, Argentina adopted a dual exchange rate regime, with a fixed exchange rate for commercial transactions and a freely floating exchange rate for capital account transactions. For these episodes, the onset of a crisis is captured by an index of exchange market pressure, which is constructed as a composite index of losses of reserves of the central bank and the dual exchange market premium. Structural VAR techniques are used to identify the effects of domestic and external shocks on the onset of the crises.

The rest of the paper is organized as follows. Section II presents a chronology of Argentina's currency crises since 1970. Section III presents a basic model to underpin the VAR specification. Section IV discusses the estimation, presents the data, and examines key empirical results. Section V concludes.

\footnotetext{
${ }^{3}$ For example, Calvo, Leiderman, and Reinhart $(1992,1996)$.
} 


\section{Chronology of the Currency Crises ${ }^{4}$}

During most of the post WWII period, Argentina experienced chronic inflation. Many stabilization programs with the exchange rate as an anchor were launched in the belief that with fixed exchange rates, domestic inflation would converge quickly to world levels. These programs also included plans of fiscal and monetary austerity (although, in most cases, they were later abandoned). All the programs ended up with currency crises. In addition to failed stabilization attempts, global external factors also contributed to the general instability of the domestic currency. Declining interest rates in the industrialized world fueled capital flows to developing countries in the late 1970s and in the 1990s and while these capital flow bonanzas are generally considered beneficial to emerging markets, they also trigger real exchange rate appreciations and current account deficits, which often lead to currency crises. Besides, these flows are prone to quick reversals whenever monetary policy in the center economies switches to a contractionary stance. Also, fragilities in the domestic financial system as well as forced conversions of deposits were another potential cause of runs against the Argentine peso. Thus, our chronology of crises will highlight the evolution of the different stabilization programs implemented in this period as well as the role of world shocks and financial vulnerabilities.

To help in our crisis chronology, Figure 1 shows the evolution of the central bank's foreign exchange reserves and the dual market premium from January 1970 to January 2002, the month of the onset of the last crisis. The dates of the currency crises are indicated by the vertical lines. It is clear from Figure 1 that almost all crises were preceded by losses of reserves or by sharp increases in the dual market premium when foreign exchange controls were introduced.

Table 1 reports crisis dates and the names of the stabilization programs preceding them as well as the time in which these programs were implemented. To gauge the severity of each crisis, Table 1 shows the loss of foreign exchange reserves of the central bank in the months leading into the crisis, the dual exchange market premium at the onset of the crisis, and the devaluations following the crisis. All speculative attacks, with the exception of the one in 1995,

\footnotetext{
${ }^{4}$ This chronology is partly based on Blejer and Liviatan (1987), Cumby and van Wijnbergen (1989), D’Amato, Grubisic, and Powell (1997), De la Torre, Levy-Yeyati, and Schmukler (2002), Di Tella and Dornbusch (1989), Dornbusch and de Pablo (1989), Edwards (2002a and 2002b), Giorgio and Sagari (1996), Hausman and Velasco (2002), IMF (2004a and 2004b), Kiguel (1989), Montanaro (1990), and Rodriguez (1994).
} 
ended with a sharp devaluation. The central bank managed to avoid a devaluation during the speculative attack of 1995, despite a 41-percent loss in foreign exchange reserves.

The first crisis and the collapse of the stabilization plan implemented by the then minister of finance José Gelbard occurred in March 1975 after various speculative attacks that resulted in a 56 percent loss of foreign exchange reserves even in the presence of many restrictions to free convertibility. ${ }^{5}$ At that time, the domestic currency in the commercial and the financial markets were devalued by 100 and 50 percent, respectively. More than a dozen additional devaluations followed over the course of the year. ${ }^{6}$

The second crisis occurred in February 1981 when a 10 percent devaluation was announced. Two other devaluations followed: 34 percent in April and 38 percent in June. This was also the collapse of the second stabilization program, the Tablita Plan, which was launched in December 1978 and characterized by a slowly declining preannounced rate of exchange rate depreciation (the "tablita”). The program also included fiscal and monetary reforms as well as a sweeping financial liberalization plan that led to the complete deregulation of domestic banking activities and a removal of capital account restrictions. This episode coincided with the capital flow bonanza fueled by the savings of OPEC economies following the 1973 oil shock and channeled to emerging markets through the eurodollar market. By 1980, the boom in capital inflows to Argentina had triggered an explosive growth in domestic credit and overall banking fragilities, which ended with the failure of two of the largest private banks as well as the liquidation of almost 100 financial institutions. ${ }^{7}$ The crisis in 1981 also coincided with the reversal in international capital flows triggered by a shift towards anti-inflationary monetary policy in the United States.

The third crisis took place in July 1982. Following the February 1981 crisis, a variety of refinancing programs to banks and insurance programs to holders of foreign currency denominated debt were implemented, maximum interest rates were reimposed and then

\footnotetext{
${ }^{5}$ Part of the exchange rate pressures led to a sharp increase in the financial market premium, which peaked at 369 percent right before the abandonment of the program.

${ }^{6}$ While during 1975 there were several devaluations, such as the devaluation experienced in June 1975 when Celestino Rodrigo was the Finance Minister, these devaluations are not examined separately. Consecutive devaluations less than six months apart from the first devaluation are considered part of the same crisis.

${ }^{7}$ See Baliño (1987) for a detailed analysis of the banking crisis in 1980-1981.
} 
abandoned, ${ }^{8}$ and dual rates were reintroduced from March to December 1981. Naturally, the continuous regulatory changes regarding interest rates and foreign exchange markets contributed to reducing investors' jittery confidence in the domestic currency and the banking sector. During this period, inflation continued to accelerate in part fueled by the bailout of the banking sector. Despite the announcement of a new stabilization plan in December 1981, the so-called Alemann Plan, inflation continued to surge fueled this time by central-bank financing of massive military spending during the Malvinas war. The economy was also hard hit by many adverse external shocks: the decrease in international commodity prices, the increase in foreign interest rates, a world-wide recession, and the beginning of the world debt crisis. After a 17-percent loss in foreign exchange reserves, the crisis culminated in July 1982 with a 148 percent devaluation, the introduction of dual exchange rates with controls on domestic interest rates and the capital account, and an exchange rate floating for the following three years.

During the floating regime, inflation continued to increase, reaching 300 percent during the first half of 1985. In June 1985, a new stabilization plan, the Austral Plan, was launched. A new currency, the Austral, ${ }^{9}$ was introduced, the dual exchange rate regime was abandoned, the domestic currency was fixed again to the dollar, and interest rate controls were eliminated. Importantly, the introduction of the Austral was accompanied by a forced renegotiation and mark down of debt contracts and banking deposits. However, while inflation was contained, the annual rate of inflation was still at about 100 percent by mid-1986, forcing the government to abandon the peg. The government tried to save the program with repeated rounds of enforcement and then relaxation of price controls and other restrictions with no success. In the first nine months of 1987, reserves of the central bank declined by 1.5 billion dollars (60 percent), leading to a collapse of the Austral Plan in 1987, with the domestic currency being devalued by 16 percent in September and by 33 percent in October.

The next two currency crises occurred in the midst of a hyperinflation period. ${ }^{10}$ The first crisis occurred in April 1989, with a 387 percent devaluation. The second crisis erupted within eight months, with a 175 percent devaluation in December 1989 and a 220 percent devaluation in

\footnotetext{
${ }^{8}$ See Baliño (1987) and Machinea and Fanelli (1987) for a detailed analysis of the measures adopted during this period.

${ }^{9}$ One Austral was equivalent to 1,000 pesos.

${ }^{10}$ From the collapse of the Austral Plan in September 1987 to the implementation of the Convertibilty Plan in 1991, prices in Argentina increased 4,500 times.
} 
February 1990. Again during this period, there were two stabilization attempts: The Primavera Plan in August 1988 and the BB Plan in December 1989. Both plans included price controls, dual exchange rates, and fiscal and monetary contraction. In both plans, monetary and fiscal restraints were rapidly abandoned and investors' confidence immediately deteriorated. In December 1989, the government froze most domestic austral-denominated time deposits and converted them to 10-year dollar denominated bonds, the Bonex. The value of these bonds immediately dropped to less that 30 percent of face value, weakening investors' faith in the domestic currency.

The last two currency crises were in early 1995 and in January 2002. In April 1991, the Convertibility Plan was launched. Its main feature was the creation of a currency board to enforce the 1-to-1 peg of the peso to the dollar. ${ }^{11}$ The plan also included a series of privatization and deregulation measures as well as fiscal reforms. Also in the early 1990s, Argentina, along with other emerging markets, witnessed another round of capital inflows triggered by declining interest rates in the United States together with the 1989-1990 Brady Plan agreement for Mexico and other Latin American countries. As in the late 1970s, capital inflows led to a domestic credit explosion and to consumption, real estate, and stock market booms. The real exchange rate appreciated and the current account deteriorated. In 1994, the shift back to a tight monetary policy in the United States ${ }^{12}$ led to worldwide interest rate increases, contributing to banking fragilities and a credit crunch amid a severe recession in Argentina. Following the Mexican crisis in December 1994, Argentina's banking system suffered from large deposit withdrawals. As investors converted pesos into dollars, the central bank's reserves decreased sharply (41 percent in the first quarter of the year), marking the first currency crisis of the Convertibility Plan. At that time, however, the convertibility program did not end up with a devaluation of the domestic currency and the reversal of capital flows to Argentina was only transitory.

By the end of 1995, capital flows not only had resumed but even surpassed the levels reached before the Mexican crisis. Capital flows to Argentina and Latin America continued to grow even in the midst of the 1997-1998 Asian crisis. Eventually, these flows started to diminish as the behavior of international capital markets changed drastically during the Russian crisis and the collapse of Long Term Capital Management in the Fall of 1998. This time around,

\footnotetext{
${ }^{11}$ The monetary reform in January 1992 replaced the austral with the peso at a rate of 10,000 australs for 1 peso.

${ }^{12}$ The Federal Funds interest rate was raised by 250 basis points in 1994 alone.
} 
as in the mid 1980s, the collapse in capital flows was of a more permanent nature. Argentina still fared comparably better than other countries in the region, with capital flows to Argentina still relatively high in the last half of 1999. The relief was however only temporary as capital flows to Argentina completely dried out in the last half of 2000 and especially in 2001. By this time, political uncertainty (President Menem's desire to remain in power for a third term) as well as financial turmoil following Brazil's crisis in January 1999 had severely affected private investment and consumption in Argentina, with economic activity plummeting through 2001. As the situation continued to deteriorate, the government sought more financing. When the government found it difficult to reschedule its debt, it resorted to compulsory placing of government bonds at banks, with banks becoming increasingly more exposed to government default. By June 2001, a massive bank run had started, sealing the fate of the currency board. In December, the government announced a deposit freeze, foreign exchange controls, and a debt moratorium. The currency board was formally abandoned in January 2002 with a 40 percent devaluation of the peso. The convertibility regime was replaced with a dual exchange rate system based on an official exchange rate of 1.4 pesos per dollar for the public sector and most traderelated transactions while all other transactions were conducted at market rates. On February 11, the dual exchange rate was abolished and the peso depreciated to 1.8 pesos per dollar. By June 2002, the exchange rate had reached 4 pesos per dollar.

\section{A Basic Model}

The numerous crises in Argentina in the last quarter of a century have stirred a heated debate about the causes behind the periodic collapses of the peg. Throughout the years, several explanations have been offered. Many argue, as it is also evident in our chronology, that at the heart of the crises are large fiscal deficits, leading to rapid growth in money creation and eventually to a depletion of reserves that make the peg unsustainable. Another view stresses that crises erupt because of real exchange rate misalignments brought about by exchange-rate based stabilization plans ${ }^{13}$ or by devaluations in neighboring countries. According to this view, the exchange rate misalignment eventually leads to unsustainable current account deficits and to speculative attacks against the domestic currency. Another version of the "real appreciation" theory of currency crises links the real appreciation with protracted recessions and with

\footnotetext{
${ }^{13}$ See, for example, Reinhart and Végh (2002).
} 
governments' inability to defend the peg in bad times. For example, Drazen and Masson (1994) conclude that in the presence of persistent unemployment, a tough policy (such as one required by the commitment to the currency board in Argentina in the late 1990s) may lower rather than raise the credibility of a no-devaluation pledge and thus trigger a currency attack.

The crises of the 1990s brought to the spotlight the fact that crises may be of a contagious nature. While crises could be synchronous across countries because of a common adverse shock (i.e. a rise in world interest rates), crises may spillover when the infected country is linked to others via trade or finance. For example, Kaminsky, Lyons, and Schmukler (2004) argue that the 1994 Mexican crisis spread to Argentina and Brazil via mutual fund withdrawals as mutual fund managers scrambled for liquidity following investors' major redemptions from mutual funds specializing in Latin America. Similarly, Kaminsky and Reinhart (2000) conclude that the Mexican default in 1982 propagated to all Latin American countries when U.S. banks, badly damaged by the Mexican default, tried to rebalance the overall risk of their portfolios by calling loans and drying up credit lines not only in Mexico but also in all the Latin American countries where they had exposure. Calvo (1999) provides a different interpretation of the collapse of the peg, which he labels "the sudden stop" syndrome. While this view shares with previous views the acknowledgment of fiscal unsustainability and real exchange rate misalignment problems, it places strong emphasis on international financial shocks. At the core of Calvo's explanation lies an unexpected and persistent stop in international capital flows, such as the one observed following the Russian crisis in August 1998. As explained in Calvo, Izquierdo, and Talvi (2002), the unexpected slowdown in capital flows forces emerging economies, such as Argentina, to drastic adjustments of their current account deficits to accommodate the shortage of external credit. Naturally, a real exchange rate adjustment becomes the essential ingredient for this adjustment to take place. With sticky prices, this adjustment can only be accomplished with a devaluation.

Finally, Kiguel and Neumeyer (1995) and Ericsson and Kamin (1993) among others, have emphasized investors' jittery confidence in Argentina's domestic currency and the banking sector due to the continuous changes in regulations on interest rates and foreign exchange markets as well as the forced conversions of bank deposits in 1985, 1989, and 2001 as triggers of runs against the peso. This section will incorporate these features into a small open economy model, which will be estimated afterwards. 
As examined above, the monetary authority in Argentina alternated between the adoption of fixed and dual exchange rate systems. For example, a fixed exchange rate and full convertibility for both current and capital account transactions were at the core of the Tablita Plan and the Convertibility Plan while a dual exchange rate system was introduced during the Gelbard Plan (1973-1975). In most cases, when the peg collapsed, the central bank allowed the

exchange rate to float for some time. Our model should reflect these changing exchange rate regimes. This section discusses two versions of the model that respectively capture the stylized features of each system.

\section{The Fixed Exchange Rate Regime}

The model is a discrete-time model of an open economy with a fixed and unique exchange rate. The government has a predefined goal for domestic credit, not necessarily consistent with the goal of a fixed exchange rate. Fixing the exchange rate is a secondary goal that can be abandoned if it hinders discretionary monetary policy. This assumption seems to capture quite well monetary and exchange rate policies in Argentina in the post WWII period. Investors realize that these two goals might conflict and expect the central bank to abandon the peg when it runs out of reserves as in Krugman (1979). We follow Blanco and Garber (1986) to model the onset of the crisis with a twist. In that paper, the authors only focus on the effect of money supply shocks. Here, we extend their model to account for foreign shocks as well as other domestic shocks, such as fiscal policy.

The money market is the central component of our model. Equilibrium in that market is given by the following equation,

$$
m_{t}-p_{t}=-\alpha i_{t}+\beta c_{t}+\gamma y_{t}+\mu_{t}^{d},
$$

where $m$ and $p$ are respectively the logarithms of the money stock and the price level, $i$ is the domestic interest rate, $y$ is the aggregate output level, and $\mu^{d}$ represents money demand shocks. A negative money demand shock can capture investors' shift out of pesos into dollars in the midst of the financial instability of the 1980s or the run against deposits due to confiscation risk in 2001. A new feature of the money demand is the component $c$. As we will examine in more detail below, this component will try to capture shifts in international investors' perception about emerging markets. For example, an increase in $c$ could capture international investors' renewed interest in emerging markets following the resolution of the debt crisis, with a decline in $c$ 
typifying the sudden stop syndrome such as the one triggered by the Russian crisis of August 1998 or a contagion effect, such as the reversal in capital flows following the 1994 Mexican crisis.

In the open economy, interest rates and prices are determined by

$$
\begin{aligned}
& i_{t}=i_{t}^{*}+E_{t} e_{t+1}-e_{t}+\rho_{t} \\
& p_{t}=e_{t}-q_{t},
\end{aligned}
$$

where $i^{*}$ is the world interest rate, $e$ is the logarithm of the nominal exchange rate, $\rho$ is the risk premium, $q$ is the log of the real exchange rate, and $E$ is an expectations operator. Equation (2) allows for deviations from interest parity. Equation (3) allows for deviations from purchasing parity. In equation (3), the log of the foreign price level is normalized to zero. Money supply in the fixed exchange rate system can be written as follows:

$$
m_{t}=d_{t}+r_{t},
$$

where $r$ is the ratio of foreign exchange reserves of the central bank to domestic credit in foreign currency and $d$ is the logarithm of the domestic credit component of the money base. In this simple model, changes in domestic monetary policy or changes in bank credit to the private sector, changes in the world interest rate, shocks to money demand and sudden stop or contagion effects will determine the evolution of reserves of the central bank. When reserves are depleted, the central bank will not be able to intervene in the foreign exchange market any longer and will have to let the exchange rate float. Using the money-market clearing conditions, we can determine the equilibrium flexible exchange rate $\tilde{e}_{t} \cdot{ }^{14}$

$$
d_{t}+\alpha\left(i_{t}^{*}+\rho_{t}\right)-\beta c_{t}-\gamma y_{t}+q_{t}=(1+\alpha) \tilde{e}_{t}-\alpha E_{t} \tilde{e}_{t+1} .
$$

To obtain the time path of the permanently floating exchange rate $\tilde{e}$, we need to specify the stochastic processes that govern domestic credit, risk premium, foreign interest rates, the real exchange rate, output, and the "sentiment” of international investors towards emerging markets.

$$
\begin{aligned}
& d_{t}=\phi g_{t}+d_{t-1}+\mu_{t}^{s} \\
& \rho_{t}=\rho+\mu_{t}^{g} \\
& i_{t}^{*}=i_{t-1}^{*}+\mu_{t}^{*}
\end{aligned}
$$

\footnotetext{
${ }^{14}$ In a pure flexible exchange rate regime, by assumption, the stock of reserves of the central bank drops to zero.
} 


$$
\begin{aligned}
c_{t} & =c_{t-1}-\omega i_{t}^{*}+\mu_{t}^{c} \\
g_{t} & =g_{t-1}+u_{t}^{g} \\
q_{t} & =\delta q_{t-1}-\chi \mu_{t}^{s}+\mu_{t}^{q} \\
y_{t} & =\bar{y}+\lambda q_{t}+\mu_{t}^{y}
\end{aligned}
$$

where $g$ is the fiscal deficit, $\bar{y}$ is the full employment level of output, and $\mu^{s}, \mu^{g}, \mu^{*}, \mu^{c}$, $\mu^{y}$ are shocks to money supply, to fiscal policy, to world interest rates, foreign investors’ sentiment towards emerging market assets (either exuberance or sudden stop/contagion syndrome), and the shock to aggregate demand. Finally, $\mu^{q}$ captures exogenous shocks to the real exchange rate. For example, it may reflect nominal devaluations in trading-partner countries, such as the Brazilian depreciation in January 1999. The shocks $\mu^{j}$ are normallydistributed white noise shocks with zero mean and standard deviation $\sigma_{j}$, for $j \in\{d, y, s, g, *, c, q\}$.

Equation (6) represents the domestic credit process. In (6), we allow fiscal imbalances to be (partly or totally) financed by money creation. Equation (7) captures a time-varying risk premium, with fiscal deficits triggering higher premium. ${ }^{15}$ Equation (8) reflects the process followed by the world interest rate. Equation (9) captures investors' interest in emerging markets. Naturally, this interest cannot just be explained by shocks to risk aversion triggered by say, the resolution of the debt crisis in 1989. Fluctuations in interest rates in financial centers can also affect the reallocation of portfolios towards emerging economies. This is why increases in $i *$ in equation (9) affect adversely the reallocation of portfolios towards emerging economies. In equation (10), we model fiscal policy as an exogenous process. Equation (11) models the real exchange rate as a mean reverting process. We allow the real exchange rate to be affected by monetary shocks since expansionary monetary policy in fixed exchange rate regimes will lead to higher inflation and a transitory real appreciation as examined in Reinhart and Végh (2002). We also allow for other exogenous shocks to the real exchange rate. With these shocks, we would

\footnotetext{
${ }^{15}$ In models with sovereign debt, risk premium is always associated with the possibility of default. It is argued that as debt increases, it may become unsustainable or the country may become unwilling to pay back. These models suggest including foreign debt as an explanatory variable for risk. Unfortunately, for empirical purposes, we cannot relate the risk premium to foreign debt because debt statistics are at best only available at annual frequencies and our estimations use monthly data. Since in Argentina, governments deficits have been associated with foreign borrowing, we include the fiscal indicator, for which we have monthly data, as the determinant of the premium.
} 
like to capture the effects of a depreciation in a trading-partner country, such as the effect of the devaluation of the Brazilian real in January 1999. Finally, output deviates temporarily from the full employment level with fluctuations of the real exchange rate or in response to other aggregate demand shocks. The relationship between the real exchange rate and economic activity in equation (12) is ambiguous since a real depreciation can increase competitiveness and fuel demand for domestic goods, but also lead to contractionary effect because of liability dollarization (Céspedes, Chang, and Velasco (2004)).

Using equations (5)-(12), we obtain the equilibrium flexible exchange rate:

$$
\tilde{e}_{t}=d_{t}+\alpha(1+\beta \omega) i_{t}^{*}+\alpha \rho-\beta c_{t}-\gamma \bar{y}+\left[\frac{1-\gamma \lambda}{(1+\alpha)-\alpha \delta}\right] q_{t}+\alpha \phi g_{t}-\frac{1}{1+\alpha}\left(\mu_{t}^{d}+\gamma \mu_{t}^{y}-\alpha \mu_{t}^{g}\right)
$$

The exchange rate depreciates in response to expansionary monetary shocks, fiscal deficits, and positive shocks to world interest rates; it appreciates in response to positive output shocks, increases in investors' interest in emerging markets, and positive money demand disturbances. Finally, a real exchange rate depreciation has an ambiguous effect on the equilibrium flexible nominal exchange rate. The decline in domestic prices triggering the real depreciation leads to higher real money balances and lower domestic interest rates, which fuel a depreciation of the nominal exchange rate. But the real depreciation may stimulate economic activity and demand for money, which results into an appreciation of the equilibrium exchange rate.

The peg will collapse at time $t+1$ if $\tilde{e}_{t+1}>e$. Thus, the time $t$ probability of a currency collapse in the next period can be written as follows:

$$
1-F\left(k_{t}\right)=\operatorname{Pr}\left[v_{t+1}>k_{t}\right]
$$

where

$$
\begin{aligned}
& v_{t+1}=\theta_{1} \mu_{t+1}^{g}+\theta_{2} \mu_{t+1}^{*}+\left(1-\theta_{3}\right) \mu_{t+1}^{s}+\theta_{3} \mu_{t+1}^{q}-\beta \mu_{t+1}^{c}-\theta_{4}\left(\gamma \mu_{t+1}^{y}+\mu_{t+1}^{d}\right) \\
& k_{t}=e-d_{t}-\phi(1+\alpha) g_{t}-\theta_{2} i_{t}^{*}-\theta_{3} q_{t}-\alpha \rho+\beta c_{t}+\not \bar{y}
\end{aligned}
$$

and $F^{\prime}\left(k_{t}\right)>0, \theta_{1}=\phi(1+\alpha)+\alpha /(1+\alpha) ; \theta_{2}=\alpha(1+\beta \omega)+\beta \omega, \theta_{3}=\frac{1-\gamma \lambda}{1+\alpha(1-\delta)}, \theta_{4}=\frac{1}{(1+\alpha)}$.

Knowing the distribution function of the shocks $F\left(k_{t}\right)$, agents can form expectations of the future exchange rate based on the average of the current fixed exchange rate and the rate 
expected to materialize conditional on a devaluation, both weighed by the respective probabilities of occurrence:

$$
E_{t} e_{t+1}=F\left(k_{t}\right) e+\left[1-F\left(k_{t}\right)\right] E_{t}\left(\tilde{e}_{t+1} \mid v_{t+1}>k_{t}\right)
$$

After linearizing equation (15), we can solve the model in equations (1)-(4) and obtain the path of reserves in the fixed exchange-rate system when there is a chance that there will be an abandonment of the peg:

$$
r_{t}=\eta_{0}-\eta_{1}\left(d_{t}-e\right)-\eta_{2} i_{t}^{*}+\eta_{3} c_{t}+\eta_{4} y_{t}-\eta_{5} g_{t}+\eta_{6} q_{t}+\mu_{t}^{d}
$$

The coefficients $\eta_{i}$ are function of the parameters of the distribution of the shocks and of the structural parameters of the model. Reserves will fall with expansionary monetary and fiscal policies, and with hikes to world interest rates. In contrast, a positive shock to money demand or demand for domestic goods as well as investors' shift towards emerging markets lead to an increase in foreign exchange reserves. Shocks to the real exchange rate have an ambiguous effect on reserves. The VAR to be estimated is based on equations (6)-(12) and (16).

\section{The Dual Exchange Rate Regime}

To relieve balance-of-payment pressures on foreign exchange reserves, albeit temporarily, Argentina implemented dual rates in the early 1970s and in the 1980s, with a fixed exchange rate for trade account transactions and a flexible exchange rate for all other transactions. We now proceed to develop a simple model of the economy under a dual-rate regime to examine the behavior of the central bank's foreign exchange reserves and the dual market premium.

The core of our model is still the money market equilibrium condition given by equation (1). Prices continue to be determined by equation (3). The interest parity condition is now written as follows:

$$
i_{t}=i_{t}^{*}+E_{t} f_{t+1}-f_{t}+\rho_{t}
$$

where $f_{t}$ is the log of the exchange rate for non-trade account transactions. Note that in equation (2') it is assumed that the purchase and sale of assets as well as the interest rate proceeds are channeled through the non-trade account exchange rate market. Using (1), (2'), and (3), we can write the equilibrium condition in the money market as

$$
d_{t}+r_{t}-e+\alpha\left(i_{t}^{*}+\rho_{t}\right)-\beta c_{t}-\gamma y_{t}+q_{t}-\mu_{t}^{d}=\alpha f_{t}-\alpha E_{t} f_{t+1}
$$


where $e$ is the fixed exchange rate for trade account transactions. Note that reserves at the central bank can still change in response to trade account imbalances because the central bank intervenes to keep the commercial rate fixed. A persistent deficit in the trade account may deplete reserves holdings. When reserves are depleted, the central bank will not be able to intervene again in the foreign exchange market and will have to allow the commercial rate to depreciate. We assume that the foreign exchange rate market is unified after the abandonment of the peg.

Naturally, investors will try to forecast as best as they can the time and the size of the devaluation. To examine the likelihood of a devaluation, we need to describe the behavior of the trade account. We assume that the trade account depends on the real exchange rate:

$$
R_{t}-R_{t-1}=\kappa q_{t},
$$

The probability of a unique floating exchange rate can be written as:

$$
\operatorname{Pr}\left(R_{t+1} \leq 0\right)=\operatorname{Pr}\left[\kappa\left(\mu_{t+1}^{q}-\chi \mu_{t+1}^{s}\right) \leq-R_{t}-\kappa \delta q_{t}\right] .
$$

Equation (19) indicates that a devaluation in a trading partner (a negative $\mu^{q}$ ) will deteriorate the trade account and increase the probability of a currency crisis. Similarly, expansionary domestic monetary policy will trigger higher prices and a real appreciation of the domestic currency and a deteriorating trade balance. In the event of a currency crisis, the exchange rate market will be unified with the exchange rate equal to $\widetilde{\mathrm{e}}$. Note that the expected future value of the financial exchange rate can be written as

$$
E_{t} f_{t+1}=\operatorname{Pr}\left(R_{t+1} \leq 0\right) \tilde{e}_{t+1}+\left[1-\operatorname{Pr}\left(R_{t+1} \leq 0\right)\right] E_{t}\left(f_{t+1} \mid R_{t+1}>0\right)
$$

The expected financial exchange rate is a non-linear function of monetary and fiscal shocks, investors' preference for emerging markets, world interest rates, output, and real exchange rate shocks. To aid in the solution, we linearize equation (20). Instead of evaluating separately the path of the financial rate and foreign exchange reserves, we follow the crisis literature and estimate an index of severity of the speculative attack by using a composite indicator tracking foreign exchange reserve losses and the dual market premium. ${ }^{16}$

$$
\left(f_{t}-e\right)-\Delta R_{t}=\tau_{0}+\tau_{1}\left(d_{t}-e\right)+\tau_{2} i_{t}^{*}-\tau_{3} c_{t}-\tau_{4} y_{t}+\tau_{5} g_{t}-\tau_{6} q_{t}-\mu_{t}^{d}
$$

\footnotetext{
${ }^{16}$ In the crisis literature, the index of exchange market pressure is a composite index that incorporates reserve losses of the central bank, the rate of exchange rate depreciation, and hikes in interest rates. See, for example, Eichengreen, Rose, and Wyplosz (1994) and Kaminsky and Reinhart (1999). Here, we adapt the index to account for the buildup of pressure in the dual exchange rate market.
} 
where $\Delta R$ is the percent change in foreign exchange reserves of the central bank. In (21), the index of exchange-market pressure increases with expansionary monetary and fiscal policy, and positive hikes in world interest rates; it decreases with positive shocks to economic activity and money demand as well as with higher investors' interest in emerging markets. In Section IV, the VAR specification that corresponds to the dual markets system is based on equations (6)-(12) and (21).

\section{Explaning the Nature of Currency Crises}

This section applies the models described in Section III to identify the nature of the shocks triggering a speculative attack. First, we describe the estimation methodology. Second, we discuss the data, and finally we elaborate on the results.

\section{The VAR}

Our theoretical model implies estimating the following system:

$$
\begin{aligned}
& A X_{t}=A(L) X_{t-1}+C \mu_{t}, \\
& V\left(\mu_{t}\right)=\Sigma .
\end{aligned}
$$

where $X$ is the vector of variables $\left[i^{*}, c, g, y,(d-e), q, \hat{r}\right], \hat{r}$ is the level of foreign exchange reserves as a proportion of domestic credit during the episodes of fixed exchange rates and is a composite index of reserve losses and the dual market premium in episodes with capital account inconvertibility, and $\mu$ is the vector of the structural shocks, $\left[\mu^{*}, \mu^{c}, \mu^{g}, \mu^{y}, \mu^{s}, \mu^{q}, \mu^{d}\right]$. The theoretical framework of Section III provides guidelines for imposing zero restrictions on the elements of $A, A(L)$ and $C$.

$A(L)$ is a matrix polynomial of order $n$, where $n$ is the number of lags, and $C$ is a full rank matrix. The covariance matrix of the structural innovations is denoted by $\Sigma$. Under the assumption of zero correlation across innovations, $\Sigma$ is diagonal. The matrices $A$ and $C$ capture the contemporaneous interactions between all the variables in the system.

We can now obtain the reduced-form VAR representation by multiplying both sides of (22) by $A^{-1}$ :

$$
X_{t}=B(L) X_{t-1}+\varepsilon_{t} .
$$

$\mathcal{\varepsilon}$ is the vector of reduced-form innovations, $\left[\mathcal{\varepsilon}^{*}, \mathcal{E}^{c}, \mathcal{\varepsilon}^{g}, \mathcal{\varepsilon}^{y}, \mathcal{\varepsilon}^{s}, \mathcal{\varepsilon}^{q}, \varepsilon^{d}\right]$. The structural and reduced-form innovations are related by the following equation: 


$$
\varepsilon_{t}=A^{-1} C \mu_{t} .
$$

The identification restrictions for both the unified and the dual exchange-rate models, as implied by the analysis of the previous section, can be summarized as follows:

$$
\begin{aligned}
& \varepsilon^{*}=\mu^{*} \\
& \varepsilon^{c}=\gamma_{21} \mu^{*}+\mu^{c} \\
& \varepsilon_{t}^{g}=\mu_{t}^{g} \\
& \varepsilon^{y}=\gamma_{46} \mu^{q}+\mu^{y} \\
& \varepsilon^{s}=\gamma_{53} \mu^{g}+\mu^{s} \\
& \varepsilon^{q}=\gamma_{65} \mu^{s}+\mu^{q} \\
& \varepsilon^{\hat{r}}=\gamma_{71} \mu^{*}+\gamma_{72} \mu^{c}+\gamma_{73} \mu_{t}^{g}+\gamma_{74} \mu^{y}+\gamma_{75} \mu^{s}+\gamma_{76} \mu^{q}+\mu^{d}
\end{aligned}
$$

Note that the parameters $\gamma$ are functions of the structural parameters in the system, such as the degree of monetization of the fiscal deficit, and these may be changing over time. For example, with fixed exchange rates and capital mobility, central banks lose their ability to conduct an independent monetary policy. This is not the case with a dual exchange rate regime, making it necessary to estimate the systems for each exchange rate regime separately. Even within a particular exchange rate regime, parameters may vary. For example, the hard peg of 1991, approved by law, certainly introduced more barriers to the conduct of monetary policy than the fixed exchange rate regime implemented in the late 1970s. Again, we need to test parameter stability within a given exchange rate system.

\section{The Data}

Figure 2 shows the evolution of domestic and external indicators from January 1970 to December 2001, the month preceding the last crisis. ${ }^{17}$ All the indicators are at a monthly frequency so we can track closely the onset of domestic and external vulnerabilities. The dates of the currency crises are indicated by the vertical lines. The top two panels show the evolution of monetary and fiscal factors. Domestic credit in dollars (including both credit to the public and private sector), shown in the left panel, provides a measure of possible inconsistency between the fixed exchange rate and monetary shocks. The central government deficit (annualized as a proportion of GDP), shown in the right panel, provides a measure of government debt sustainability. While a broader measure of the public sector would have been more appropriate to

\footnotetext{
${ }^{17}$ See the Data Appendix for data sources and definitions.
} 
measure the fiscal stance, long high frequency time series on local governments and public enterprises are not available. $^{18}$

The middle panels show the effective real exchange rate (a depreciation is shown as an increase in the real exchange rate index) and the index of manufacturing production. The bottom left panel shows the behavior of the world real interest rate, captured by the U.S. real interest rate. Finally, the bottom right panel shows the first principal component of foreign exchange reserves ${ }^{19}$ of the five largest Latin American countries (with the exception of Argentina), Brazil, Chile, Colombia, Mexico, and Venezuela. With this index, we try to provide a measure of investors' sentiments towards Latin America. Investors' overall enthusiasm about Latin American markets translates into increases in the first principal component of foreign exchange reserves held by central banks, while worries about Latin America lead to losses of foreign exchange reserves across Latin American countries, again as captured by the first principal component of reserves. Since increases in foreign exchange reserves of central banks can also be affected by changes in interest rates in financial centers, we will separately identify in our estimations the effect of shocks to investors' preferences (possibly capturing contagion effects) and world interest rate shocks on the fluctuations of the first principal component (as shown in equation 9).

\section{The Results}

As discussed in the chronology, we divided our sample into fixed and dual exchange rate regimes. The fixed exchange rate regimes include the Tablita, Alemann, Austral, and Convertibility Plans ${ }^{20}$ while the dual exchange rate regimes include the Gelbard, Primavera, and BB Plans.

Macropolicies and credibility may vary across and within stabilization plans, affecting the transmission of shocks and making it necessary to test for parameter stability. Since periods with dual exchange rate regimes are very short, we cannot test this hypothesis. Thus, we

\footnotetext{
${ }^{18}$ Information on public sector debt is available, although not at a monthly frequency.

${ }^{19}$ It would have been preferable to use international capital flows data to emerging markets to proxy "investors' interest in emerging markets." However, capital flow data is at best only available at quarterly or even annual frequencies.

${ }^{20}$ While during the Tablita and Convertibility Plans there were never controls on foreign exchange transactions, at times during the Alemann and Austral Plans, the government allowed different rates for financial and commercial exchange rate transactions. Still, we include these last two episodes in our estimations of the fixed exchange rate episodes because when these plans were launched, a unique exchange rate regime was implemented.
} 
estimate a unique VAR for the Gelbard, Primavera, and BB Plans and the currency crises that followed the implementation of those plans. Since the fixed exchange rate regimes episodes are longer-lasting, we test for parameter stability during these episodes. ${ }^{21}$ We test for three structural breaks. We examine whether the transmission mechanism during the Tablita-Alemann-Austral periods is different from that of the Convertibility Plan. We also test for two structural breaks during the Convertibility Plan: the crisis in April 1995 (following the Mexican crisis) and the Brazilian crisis in January 1999. We find that the transmission mechanism during the TablitaAlemann-Austral is different from that of the Convertibility Plan. We also find a structural break in the aftermath of the Brazilian crisis. Thus, our results for the fixed exchange rate episodes will include three VAR systems: The first includes the Tablita, Alemann and Austral Programs; the second one refers to the Convertibility program from its implementation in April 1991 to December 1998; while the third episode starts in January 1999 with the Brazilian devaluation and ends with the collapse of the currency board in January 2002.

As examined above, our VARs include seven variables: the world real interest rate, the first principal component of foreign exchange reserves of Brazil, Chile, Colombia, Mexico, and Venezuela, government deficit (as a proportion of GDP), industrial production, domestic credit in dollars, the real exchange rate, and foreign reserves ( or the index of exchange market pressure for the dual periods). However, in light of the unavailability of data series on industrial production during the Gelbard Plan (1973-1975), the VAR for the dual exchange rate regimes only includes six variables. Although some of our variables turned out to be $\mathrm{I}(1),{ }^{22}$ we estimate an unrestricted VAR in levels in order to allow the data to pick up the underlying long-run cointegrating relationship. We allow for 2 lags in all three systems ${ }^{23}$, which was sufficient to produce serially uncorrelated residuals. ${ }^{24}$

\footnotetext{
${ }^{21}$ To test whether VARs were different, we introduced slope dummies representing various periods into the reserves equation, with a significant slope dummy implying that transmission mechanisms were different across different periods.

${ }^{22}$ Dickey-Fuller tests failed to reject the unit root hypothesis for the first principal component of foreign exchange reserves of the five largest Latin American economies, foreign exchange reserves of the central bank of Argentina, the industrial output and money variables at the 5 percent significance level (although we got mixed results on money variables, depending on number of lags ultimately chosen). The hypothesis was rejected for the world real interest rate, the exchange market pressure index and the deficit.

${ }^{23}$ The estimation was done with only one lag for the dual system, due to the limited number of observations for the hyperinflation episode. We also estimated the system with one lag for the 1999-2001 unified exchange rate system.

${ }^{24}$ Slope dummies were introduced for hyperinflation periods and for periods in which no stabilization plan was being implemented. Based on the model's assumptions and significance levels of variables, we formulate the world
} 
We present our results in three complementary ways. First, we examine the impulse responses to assess whether we have identified correctly the various shocks, that is, whether, for example, our "money supply” shock leads to a decline in foreign exchange reserves of the central bank as the first generation model of currency crises described in Section III predicts. Second, we report the variance-decomposition of reserves during the fixed exchange rate regimes and of the index of exchange market pressure during dual exchange rate regimes to assess the importance of domestic and foreign shocks. The variance decompositions provide us with a yardstick of the average role of each shock over the whole estimation period, that is, during both tranquil and crisis times. In some cases, such as during dual exchange rate periods, the variance decompositions show the importance of each shock over various stabilization plans and crisis episodes. To untangle the role of domestic and world shocks for each stabilization program and on the unfolding of the currency turbulences for each crisis examined, we then present the historical decompositions of foreign exchange reserves and the index of market pressure for the various stabilization plans and then estimate the role of each shock from the onset of the fragilities until the crisis month.

Figure 3 shows the impulse responses of the ratio of foreign exchange reserves to domestic credit (shown in percent) to domestic and external shocks during episodes of unified exchange markets. The left panels show the impulse responses during the Tablita, Alemann and Austral Plans, the middle panels show the impulse responses for the first part of the Convertibility Plan from the implementation of the currency board until the Brazilian Crisis, and the right panels show the impulse responses for the second part of the Convertibility Period from the Brazilian Crisis to the Argentine Crisis in January 2002. The top four panels show the responses to domestic shocks. The effects of shocks to money supply, government deficit, and money demand are all statistically significant and of the expected signs, with positive shocks to money supply and government deficit and negative shocks to money demand triggering losses of reserves, with somewhat more persistent effects during the Tablita-Alemann-Austral Plans. In contrast, the effects of shocks to output only show a strong and positive effect on reserves

real interest rate equation as a univariate $\operatorname{AR}(1)$. The equation for the first principal component of reserves of the five largest Latin American countries only includes lags of the world real interest rate in addition to lags of the principal component variable itself. Ultimately, we end up estimating a near VAR using SUR estimation while allowing for a Sims-Bernanke decomposition of the structural innovations. 
during the second part of the Convertibility Plan. The effect of this shock on reserves is negligible during the other two episodes as shown in Table 2.

The bottom three panels show the responses to world shocks. Shocks to the world real interest rate are only statistically significant during the Tablita-Alemann-Austral Plans and the first part of the Convertibility Plan (until the Brazilian Crisis), with hikes in world interest rates triggering losses in reserves. Since the 1990s, a continuously increasing research in international finance has emphasized the role of international investors' sentiments (or "risk appetite") in creating capital flow bonanzas to particular regions, such as Latin America in the late 1970s, Europe in the early 1990s, or East Asia in the mid 1990s. This same literature has also singled out the role of international investors' sentiments in capital flow reversals. As the impulse responses in Figure 3 show, those effects, captured by shocks to the first principal component of foreign exchange reserves, are only important during the early 1990s up to the Brazilian crisis in January 1999. Finally, shocks to the real exchange rate (attempting to capture exogenous shocks, such as trade partners fluctuations in their real exchange rates due to crises or the adoption of a stabilization plan) are never statistically significant.

Figure 4 shows the dynamic responses during Dual Exchange Rate Regimes. Domestic shocks are also important during these episodes, with positive shocks to money supply and fiscal deficits and negative shocks to money demand leading to currency turbulences as captured by reserve losses or increases in the dual market premium. While the dual market system implemented in Argentina implied the use of controls on capital flows to insulate the domestic economy from world shocks, our results indicate that fluctuations in world real interest rates and shocks to "investors' interest in emerging markets" have statistically significant effects on the index of exchange market pressure, with hikes in world interest rates and negative shocks to investors' sentiment leading to currency turmoil in Argentina. As with fixed exchange rate regimes, real exchange rate shocks are never statistically significant.

Tables 2 and 3 report the variance decompositions for the fixed exchange rate and the dual exchange rate episodes, respectively. As Table 2 shows, the shocks that move the currency market vary across all these episodes, only money demand shocks are important across the whole sample (explaining between 18 and 80 percent of the conditional variance of foreign exchange reserves at all horizons), suggesting that changes in rules as well as improvement or abandonment of property rights affect dramatically households' behavior and are at the core of 
all bonanzas and crises in Argentina. Interestingly, the period starting in April 1991 with the adoption of the currency board until the Brazilian crisis in January 1999 looks different from other episodes. During the earlier part of the currency board episode, world shocks -as captured by shocks to world real interest rates and "investors' interest in emerging markets" - account for about 20 to 70 percent of the conditional variance of foreign exchange reserves (as a proportion of domestic credit in dollars). In contrast, vulnerabilities in domestic indicators -fiscal deficits and shocks to economic activity- are the main drivers of reserve fluctuations during the last part of the Convertibility Plan, accounting for about 60 percent of the variance in foreign exchange reserve forecasting errors. Finally, currency booms and busts during the Tablita, Alemann, and Austral Plans are mostly explained by world real interest rate shocks and money supply and demand shocks (in line with the crisis chronology).

Table 3 reports the variance decomposition for the dual exchange rate episodes. Again, as during the fixed exchange rate episodes, money demand shocks explain a substantial part of currency market ups and downs (between 20 and 50 percent of the forecasting variance of the index of exchange market pressure for all horizons). The dual exchange rate episodes look very similar to the Tablita-Alemann-Austral plans, with money supply shocks and world interest rates explaining about 50 percent of the forecasting variance of the index of market pressure.

To track the effects of the identified domestic and world shocks in real-time on currency bonanzas and crises, we now present the historical decompositions of the foreign exchange reserves and the index of exchange market pressure. Figures 5 and 6 present, respectively, the decomposition for the fixed exchange rate and the dual exchange rate episodes from the implementation of each stabilization plan until the crisis. In these figures, the solid line shows the difference between the actual value of reserves or index of market pressure and the forecasted value with information at the start of the stabilization plan while the dotted lines show the part explained by either domestic or international shocks. Since the Alemann Stabilization Plan only lasted a few months and this plan also helped maintain the fixed exchange rate regime launched with the Tablita Plan, we report the historical decomposition jointly for both plans.

The results in Figure 5 indicate that the capital flow bonanza, as captured by the increases in reserves, in the year following the implementation of the stabilization plans was mostly fueled by better domestic fundamentals across all episodes. This finding agrees with the conventional wisdom in both academic and policy circles that the launching of the stabilization plans 
coincided, at least transitorily, with fiscal and monetary reforms as well as deregulation of the financial sector. ${ }^{25}$ Our results for the Tablita Plan and first part of the Convertibility Plan also show that the capital flow bonanzas in the year following the implementation of the plans were triggered by favorable external conditions. We feel confident about our identification since the implementation of the Tablita in the late 1970s and Convertibility Plans in the beginning of the 1990s coincided with episodes of low world real interest rates and with a surge in investors' interest in emerging markets following the Brady debt relief program of 1989-90. The historical decompositions in Figure 5 indicate that capital flow reversals and the onset of the crises in 1981-82 and 2001 were caused in part (totally for the crisis in 1987) by deteriorating domestic fundamentals. In contrast, the reversal in the path of reserves starting in 1994 was mostly due to unfavorable world conditions. Only during the four months preceeding the 1995 crisis were fragilities observed on the home front, mostly driven by bank deposit runs.

Figure 6 shows the historical decompositions for the stabilization plans during the dual exchange rate regimes. In this figure, we jointly examine the two stabilization plans during the hyperinflation episode. In contrast with the stabilization plans during the fixed exchange rate regimes, the implementation of the Gelbard, Primavera, and BB Plans do not fuel (even transitorily) a reduction in exchange market pressures. In the Gelbard Plan, a large part of the initial vulnerabilities are triggered by adverse external conditions, driven by hikes in world interest rates in 1974. In the stabilization plans in the late 1980s, the exchange market pressure is mostly explained by rapidly deteriorating monetary conditions. Remember that these plans take place at the height of the hyperinflation period, which only ends with the implementation of the Convertibility Plan.

Figures 5 and 6 only assess the combined effect of all domestic shocks or that of external shocks. Also, the historical decompositions in these figures cover times of both bonanza and crisis. Table 4 provides a higher resolution picture of crisis times. First, it untangles the various sources of domestic fragility into money supply, government deficit, output, and money demand shocks. Second, it sorts out the origins of external vulnerability into world real interest, investors' interest in emerging markets (or contagion), and real exchange rate shocks. Third, it concentrates on the onset of the currency turmoil until the crisis, that is, it shows the historical

${ }^{25}$ See, for example, IMF (2004a, 2004b), Blejer and Liviatan (1987), Kiguel (1989), and Machinea and Fanelli (1987). 
decompositions from the times reserves start to fall or the index of market pressure starts to increase. Each cell in this table shows the share of the fluctuations in foreign exchange reserves (or the index of exchange market pressure) explained by each single shock. As shown in Table 4, all currency crises are preceded by domestic vulnerabilities with the exception of the 1995 crisis. Monetary shocks are at the core of the domestic fragilities for all crises with the exception of the 2002 crisis, when dramatic adverse shocks to economic activity seal the fate of the currency board. Importantly, monetary shocks do not just reflect money supply shocks. In particular, money demand shocks are very important during the Tablita, Alemann, and Austral crises. As described in our chronology, these are episodes plagued by numerous regulatory changes on interest rates and foreign exchange markets -as during the period from February 1981 to June 1982- or by the stop and go cycles of controls on prices, wages and public utilities during the Austral Plan. ${ }^{26}$ Naturally, these continuous changes in rules on financial and price contracts fuel uncertainty and reduce households' faith in the financial system and overall ability of the authorities to maintain the peg. Finally, our results do not uncover an important fiscal effect at the onset of the crises. These results may be due to our "fiscal deficit" indicator that includes the central government but not the local governments and public enterprises, which ran particularly large deficits during the Tablita Plan and the latter part of the Convertibility Plan. Since our fiscal indicator captures only partially the fiscal deficit of the consolidated public sector, fiscal shocks may in fact be captured by the shocks to money supply in equation (6). ${ }^{27}$

External shocks are also important in explaining currency turbulences. For example, hikes in world interest rates have a major impact on currency vulnerabilities during the Tablita and Alemann Plans, when world real interest rates increased from -1 percent in July 1980 to

\footnotetext{
${ }^{26}$ The management of prices was a central part of the Austral Plan. Prices and wage controls were introduced at the start of the program, but the first adjustment in prices was implemented in April 1986. In July 1986, the government introduced ceilings for monthly increases in prices as well as limits on wage increases. By the last months of 1986, prices were again fluctuating freely. In February 1987, a price freeze was again announced only to be relaxed in May 1987.

${ }^{27}$ Since the results in Table 2 show that even our partial measure of fiscal shocks can explain 20 percent of the variance decomposition for foreign exchange reserves during the last part of the Convertibility Plan (January 1999December 2001), we examine the possibility of a time-varying effect of the fiscal shock. We decompose the historical decomposition in Table 4 into two episodes. The first episode starts in January 2001 from the onset of currency turmoil and lasts until July 2001. The second episode starts in August 2001 and ends in December 2001, with the collapse of the Convertibility Plan. During the first episode, increases in government deficit explain 18 percent of the losses of reserves. But on July 29, 2001, the Argentine Congress passes the "Zero Deficit Law," requiring a balanced budget by the fourth quarter of 2001. In August 2001, the deficit starts to decline while reserves losses continue to increase, explaining the almost zero cumulative net effect of fiscal shocks on reserves from January to December 2001 shown in Table 4.
} 
about 10 percent on average in 1981-1982, and during the Convertibility Plan in 1994, when the Federal Reserve increased its policy rate by 250 basis points. Indeed, our results indicate that 53 percent of the total decline in the historical forecast error of Argentina's reserves between October 1979 and June 1982 is explained by world interest rate shocks, with the world interest rate effect increasing to 69 percent in the 1995 crisis.

In the 1990s, external shocks are not limited to those fueled by changes in monetary conditions in industrialized countries. Spillover effects from other Latin American countries (as captured by a shock to investors' interest in emerging markets) magnify reserve losses triggered by monetary tightening in financial centers. Our empirical estimations suggest that about onefourth of the fall in reserves from December 1993 to February 1995 can be explained by contagion factors. However, contrary to theories advocating sudden stops as an explanation of the 2002 Argentine crisis (Calvo, Izquierdo, and Talvi, 2002), we find that adverse shocks to investors' interest in emerging markets played no role in explaining the collapse of the currency board as capital inflows had already dried up following the Russian crisis in late 1998. By 2001, investors had already started observing Argentina as a country with problems of its own.

We also examined the costs of crises fueled by domestic fragilities and those triggered by adverse external shocks even in the presence of immaculate domestic fundamentals. Table 5 shows various costs for these two types of crises. First, we looked at the severity of the crises as captured by reserve losses in the six months prior to the crises and the real exchange rate depreciation in the six months following the crises. On average, losses of reserves for crises fueled by domestic vulnerabilities reach 33 percent but only reach 16 percent for crises triggered by external shocks. Similarly, real depreciations are far larger (73 percent) for crises triggered by fragile domestic fundamentals than for crises with only adverse external shocks (5 percent). Second, we examined the crisis impact on the economy. Output losses in the year of the crisis and the following year average 5 percent for crises with domestic fragilities while the economy grows 3 percent during the crisis triggered by adverse external shocks. Finally, we examined the external adjustment following the crises. Access to international capital markets can be severely impaired in the aftermath of crises, with countries having to run sizable current account surpluses to repay their debt. We examined the size and type of the adjustment across these two types of crises. In the case of crises with domestic vulnerabilities, most of the adjustment occurs on the import side, with imports falling approximately 23 percent in the year following the crisis and 
exports only growing 21 percent despite large depreciations during this type of crisis. This evidence suggests that Argentina might have been unable to attract trade credits to finance exports when its economy was quite fragile. In contrast, in the aftermath of the 1995 crisis, booming exports were at the heart of the recovery of the current account (35 percent increase) and even imports continued to increase (10 percent).

\section{Conclusions}

Economists have puzzled at length over the causes and severity of currency crises. As a result, research in this area has surged, especially since the ERM crises in 1992-1993. Most of the empirical research has focused on predicting crises using reduced-form estimations and failed to uncover the effect of policy and structural shocks on the changing severity of currency turmoil. This paper uses an old methodology to study this new problem, implementing VAR techniques to quantify the role of different shocks in the severity of currency crises. Our case study is Argentina, a country that not only has been at the center stage in every single episode of international financial turmoil (such as the 1982 debt crisis, the 1994 Tequila crisis, and the 1999 Brazilian crisis), but also has had many currency collapses of its own. Thus, while our analysis is confined to one country, it does provide a glimpse of the nature of worldwide currency turbulences. Our results confirm previous findings in the literature but also suggest new results.

The major conclusions that emerge from our analysis are as follows. First, our estimations confirm the results obtained by Calvo, Leiderman, and Reinhart (1992) regarding the role of monetary tightening in industrial countries during the episodes of capital flows reversals of the early 1980s and mid 1990s. Both the collapse of the Tablita-Alemann Plans and the speculative attack against the peso in 1994-95 in the midst of the Convertibility Plan were in large part precipitated by the shift to a contractionary monetary stance in the United States.

Second, as expected, inconsistent monetary and exchange rate policies did trigger many

of the main speculative attacks against the peso. But, as our event chronology and historical decompositions suggest, loose monetary policy was not the only culprit. The erratic nature of capital account restrictions and interest rate and credit controls as well as the stop and go cycles on price and wage controls in the mid 1980s also played a key role- with the uncertainty triggered by forced conversion of contracts leading to capital flight and downward pressure on money demand. 
Third, the mid-1990s look somewhat different. Spillovers from Mexico and other Latin American countries seem to have been a source of financial distress for Argentina, explaining about 25 percent of the severity of the speculative attack in 1995. This is not surprising as in the 1990s the extent of integration of Latin America to international capital markets sharply increases. It is also in the 1990s when mutual funds become important players in Latin America. Naturally, this provides a new channel for spillovers, as was the case when mutual funds retreated from several countries in Latin America after the losses they suffered from the Mexican devaluation.

Fourth, the origin of the 2002 crisis lies in the sharp depression that started in the last half of 1998 and continued and deepened throughout the pre-crisis period. As the economy slided into recession, the currency board became a liability as the government was constrained to carry out a contractionnary monetary policy in the midst of a a profound recession. Financial contagion from Brazil or other Latin American countries was found to play no role in explaining the collapse of the currency board in 2001.

Finally, our results show that the participation in international capital markets can be risky and that crises may occur even in the presence of immaculate domestic fundamentals. Still, the costs of crises triggered by just adverse external shocks are far smaller than those of crises fueled by fragile domestic fundamentals. 


\section{Appendix}

The data used in the VAR estimation is at monthly frequencies and covers the periods 1970:12001:12.

\section{Data Sources:}

All data is from International Financial Statistics, IMF unless explained below.

Fundación de Investigaciones Económicas Latinoamericanas, FIEL

\section{Definitions and Units of the Variables in Figures 1 and 2:}

r: Ratio of Argentina’s Foreign Exchange Reserves to Domestic Credit in dollars, in percent.

(f-e): Percentage difference between the black/dual exchange market exchange rate and the commercial exchange rate.

$\boldsymbol{d}$-e: Total domestic credit of the banking sector, measured in billion dollars at the commercial exchange rate.

q: Real effective exchange rate with respect to Argentina's main trading partners.

$i^{*}$ : U.S. Real Interest Rate: Nominal interest rate on one-year U.S. Treasury Bills adjusted for CPI inflation (in percent).

c: First principal component of foreign exchange reserves of the following countries: Brazil, Chile, Colombia, Mexico and Venezuela. The principal component is constructed as a linear combination of the five series, where the weights correspond to the eigenvector associated with the largest eigenvalue of the covariance matrix of the individual series (See Drhymes (1974) for an explanation of principal components analysis).

g: Annualized central goverment deficit measured as a proportion of GDP, in percent. Obtained from Ministry of Finance, the IMF Government Finance Statistics and IMF Staff reports.

y: Monthly index of industrial production. FIEL database. 


\section{References}

Baliño, Tomás, (1987), “The Argentine Banking Crisis of 1980,” International Monetary Fund Working Paper WP/87/77.

Blanco, H. and P.M. Garber, (1986), "Recurrent Devaluations and Speculative Attacks on the Mexican Peso,” Journal of Political Economy, v.94. pp. 148-166.

Blejer, M. and N. Liviatan, (1987), "Hyperinflation: Stabilization Strategies in Argentina and Israel, 1985-1986,” International Monetary Fund Staff Papers, Vol. 34, No.3, September, 409-438.

Calvo, G., (1999), “The Russian Virus,” University of Maryland, mimeo.

Calvo, G., A. Izquierdo, and E. Talvi, (2002), "Sudden Stops, the Real Exchange Rate, and Fiscal Sustainability: Argentina's Lessons,” Inter-American Development Bank, mimeo.

Calvo, G., L. Leiderman, and C. Reinhart, (1992), "Capital Inflows to Latin America: The 1980s and the 1990s.” IMF Working Paper, No. 85.

Calvo, G., L. Leiderman, and C. Reinhart, (1996), “Inflows of Capital to Developing Countries in the 1990s,” Journal of Economic Perspectives, Vol. 10, No. 2, Spring.

Céspedes, L., R. Chang, and A. Velasco, (2004), "Balance Sheets and Exchange Rate Policy" American Economic Review, September.

Cumby, R.E. and S. van Wijnbergen, (1989), "Financial Policy and Speculative Runs with a Crawling Peg: Argentina 1979-1981,” Journal of International Economics, Vol. 27. pp.111-127.

D'Amato, L., E. Grubisic, and A. Powell (1997), "Contagion, Bank Fundamentals or Macroeconomic Shocks? An Empirical Analysis of the Argentine 1995 Banking Problems,” paper presented at the 1997 LACEA meetings (Bogota: Colombia).

Di Tella, G., and R. Dornbusch, eds., (1989), The Political Economy of Argentina, 1946-1983, Pittsburgh: University of Pittsburgh Press.

De la Torre, A., E. Levy Yeyati, and S. L. Schmukler, (2002). “Argentina's Financial Crisis: Floating Money, Sinking Banking,” Washington DC. World Bank.

Dornbusch, R. and J.C. de Pablo, (1989), “Debt and Macroeconomic Instability in Argentina,” in J. Sachs, ed. Developing Country Debt and the World Economy.

Drazen, A. and P. Mason, (1994), "Credibility of Policies versus Credibility of Policymakers,” Quarterly Journal of Economics, Vol. 109 No. 3, August, 735-754. 
Edwards, S., (2002a), “The Argentine Debt crisis of 2001-2002: A Chronology and Some Key Policy Issues.” Mimeo. UCLA.

Edwards, S., (2002b), “The Great Exchange Rate Debate After Argentina,” NBER Working Paper No 9257. Cambridge, Massachussets.

Drhymes, P., (1974), Econometrics: Statistical Foundations and Applications. New York: Springer-Verlag.

Eichengreen B., A. Rose and C. Wyplosz, (1994), "Speculative Attacks on Pegged Exchange Rates: An Empirical Exploration with Special Reference to the European Monetary System," in The New Transatlantic Economy. ed. by M. Canzoneri, P. Masson, and V. Grilli. Cambridge: Cambridge University Press for CEPR.

Ericsson, N. and S. Kamin, (1993), "Dollarization in Argentina," International Finance Discussion Paper No. 460. Washington D.C.: Board of Governors of the Federal Reserve.

Giorgio, L. and S. Sagari, (1996), "Argentina's Financial Crises and Restructuring in the 1980s,” Bank Restructuring: Lessons from the 1980s, A. Sherg (ed), Washington D.C.: World Bank Publications.

International Monetary Fund (2004a), “The IMF and Argentina, 1991-2001”. Independent Evaluation Office. 2004. Washington DC.

International Monetary Fund (2004b), “ Lessons from the Crisis in Argentina” Occasional Paper 236. Washington DC.

Hausman, R. and A. Velasco, (2002) “The Argentine Collapse: Hard Money's Soft Underbelly,” April, Harvard University mimeo.

Kaminsky, Graciela, (2009), “Two Hundred Years of Financial Integration: Latin America since Independence,” in http://home.gwu.edu/ graciela.

Kaminsky, G. and C. Reinhart, (2000), “On Crises, Contagion, and Confusion,” Journal of International Economics.

Kaminsky, G., R. Lyons, and S. Schmukler, (2004), "Managers, Investors, and Crises: Investment Strategies of Mutual Funds,” Journal of International Economics, Vol. 64, Issue 1, October 2004, 113-134.

Kiguel, M., (1989), “Inflation in Argentina: Stop and Go Since the Austral Plan,” Policy, Planning, and Research Working Paper No. 162, The World Bank, March.

Kiguel, M. and P. Neumeyer, (1995), "Seigniorage and Inflation: The Case of Argentina," Journal of Money, Credit, and Banking, Vol. 27, No. 3, August, 672-682. 
Krugman, P, (1979), “A Model of Balance of Payments Crises,” Journal of Money, Credit and Banking, v. 11. pp. 311-325.

Machinea, J. and J. Fanelli, (1988), “Stopping Hyperinflation: The Case of the Austral Plan in Argentina, 1985-87,” in Inflation Stabilization: The Experience of Israel, Argentina, Brazil, Bolivia, and Mexico, M. Bruno, G. Di Tella, R. Dornbusch, and S. Fischer (eds), MIT Press, 111-152.

Montanaro, E, (1990), "The Banking and Financial System in Argentina: The History of a Crisis,” The Future of Financial Systems and Services, E. Gardener, ed. New York: St. Martin's Press.

Mussa, M., (2002) Argentina and the Fund: From Triumph to Tragedy, Institute for International Economics, March.

Perry, G. and L. Servén, (2002), “The Anatomy of a Multiple Crisis: Why Was Argentina Special and What Can We Learn From It?” The World Bank, May, mimeo.

Reinhart, C. and C. Végh, (2002), "Do Exchange Rate-Based Stabilizations Carry the Seeds of Their Own Destruction?” mimeo, University of Maryland.

Rodriguez, C. (1994). “Argentina: Fiscal Disequilibria Leading to Hyperinflation,” in Easterly, Rodriguez and Schmidt-Hebel, eds. Public Sector Deficits and Macroeconomic Performance, New York: Oxford University Press 
Table 1

Stabilization Plans and Crises

\begin{tabular}{|c|c|c|c|c|c|c|}
\hline \multicolumn{2}{|c|}{ Stabilization Plans } & Crisis Date & $\begin{array}{l}\text { Reserve Losses } \\
\text { (in percent)* }\end{array}$ & \begin{tabular}{|} 
Dual Market \\
Premium on the \\
Month of the Crisis \\
(in percent)
\end{tabular} & $\begin{array}{l}\text { Devaluation on the } \\
\text { Month of the Crisis } \\
\text { (in percent) }\end{array}$ & $\begin{array}{c}\text { Cumulative } \\
\text { Devaluation } \\
\text { in the First Six } \\
\text { Months Following } \\
\text { the Crisis } \\
\text { (in Percent) }\end{array}$ \\
\hline Gelbard & May 1973 & March, 1975 & 56 & 369 & 100 & 628 \\
\hline Austral & June 1985 & September 1987 & 75 & n.a. & 16 & 133 \\
\hline Primavera & August 1988 & April 1989 & 62 & 206 & 387 & 4025 \\
\hline $\mathrm{BB}$ & July 1989 & February 1990 & 58 & 105 & 220 & 232 \\
\hline Convertibility & April 1991 & March 1995 & 41 & n.a & 0 & 0 \\
\hline
\end{tabular}

Note: * For each episode, reserve losses are computed from the month the stock of reserves held by the central bank peaks until the crisis date. 
Table 2
Variance Decomposition for Foreign Exchange Reserves During Fixed Exchange Rate Regimes

\begin{tabular}{|c|c|c|c|c|c|c|c|c|c|c|c|c|c|c|c|c|c|c|c|c|c|}
\hline \multirow[b]{3}{*}{$\begin{array}{c}\text { Horizon } \\
\text { (months) }\end{array}$} & \multicolumn{21}{|c|}{ Fraction of Variance Due to Shocks to: } \\
\hline & \multicolumn{7}{|c|}{ Tablita, Alemann, and Austral Plans } & \multicolumn{7}{|c|}{ Convertibility Plan: April 1991-December 1998} & \multicolumn{7}{|c|}{ Convertibility Plan: January 1999-January 2002} \\
\hline & \begin{tabular}{|l|} 
Money Supply \\
\end{tabular} & $\begin{array}{c}\text { Government } \\
\text { Deficit }\end{array}$ & Output & $\begin{array}{c}\text { Money } \\
\text { Demand }\end{array}$ & \begin{tabular}{|c|} 
World Real \\
Interest Rate
\end{tabular} & $\begin{array}{c}\text { Investors' } \\
\text { Interest in } \\
\text { Emerging } \\
\text { Markets }\end{array}$ & $\begin{array}{c}\text { Real } \\
\text { Exchange } \\
\text { Rate * }\end{array}$ & Money Supply & $\begin{array}{c}\text { Government } \\
\text { Deficit }\end{array}$ & Output & $\begin{array}{c}\text { Money } \\
\text { Demand }\end{array}$ & \begin{tabular}{|c} 
World Real \\
Interest Rate
\end{tabular} & $\begin{array}{l}\text { Investors' } \\
\text { Interest in } \\
\text { Emerging } \\
\text { Markets }\end{array}$ & $\begin{array}{c}\text { Real } \\
\text { Exchange } \\
\text { Rate * }\end{array}$ & Money Supply & $\begin{array}{c}\text { Government } \\
\text { Deficit }\end{array}$ & Output & $\begin{array}{c}\text { Money } \\
\text { Demand }\end{array}$ & \begin{tabular}{|c} 
World Real \\
Interest Rate
\end{tabular} & $\begin{array}{c}\text { Investors' } \\
\text { Interest in } \\
\text { Emerging } \\
\text { Markets }\end{array}$ & $\begin{array}{c}\text { Real } \\
\text { Exchange } \\
\text { Rate * }\end{array}$ \\
\hline 1 & 19 & 1 & 0 & 80 & 0 & 0 & 0 & 6 & 8 & 0 & 81 & 0 & 4 & 0 & 0 & 10 & 15 & 71 & 3 & 0 & 0 \\
\hline 2 & 17 & 2 & 0 & 80 & 1 & 0 & 0 & 4 & 7 & 0 & 77 & 3 & 9 & 1 & 2 & 17 & 33 & ${ }_{44}$ & 1 & 1 & 1 \\
\hline 3 & 16 & 3 & 2 & 76 & 2 & 0 & 0 & 4 & 6 & 0 & 69 & 7 & 13 & 1 & 3 & 19 & 40 & 33 & 1 & 2 & 2 \\
\hline 4 & 16 & 3 & 5 & 70 & 5 & 0 & 0 & 4 & 5 & 0 & 61 & 11 & 17 & 1 & 4 & 20 & 43 & 28 & 1 & 2 & 2 \\
\hline 5 & 17 & 3 & 7 & 65 & 8 & 0 & 0 & 5 & 5 & 0 & 55 & 14 & 20 & 1 & 4 & 20 & 45 & 25 & 1 & 3 & 2 \\
\hline 6 & 17 & 3 & 9 & 59 & 11 & 0 & 0 & 5 & 4 & 0 & 50 & 17 & 22 & 1 & 5 & 20 & 45 & 23 & 1 & 3 & 3 \\
\hline 7 & 17 & 3 & 10 & 55 & 15 & 0 & 0 & 5 & 4 & 0 & 46 & 19 & 25 & 1 & 5 & 21 & 46 & 22 & 1 & 4 & 3 \\
\hline 8 & 18 & 3 & 10 & 50 & 18 & 0 & 0 & 5 & 4 & 0 & 43 & 21 & 26 & 1 & 5 & 21 & 46 & 21 & 1 & 4 & 3 \\
\hline 9 & 18 & 3 & 11 & 46 & 21 & 0 & 0 & 5 & 3 & 0 & 40 & 23 & 28 & 1 & 5 & 21 & 46 & 21 & 1 & 4 & 3 \\
\hline 10 & 18 & 3 & 11 & 43 & 24 & 0 & 0 & 5 & 3 & 0 & 38 & 24 & 29 & 1 & 5 & 21 & 46 & 20 & 1 & 4 & 3 \\
\hline 11 & 19 & 3 & 11 & 40 & 27 & 0 & 0 & 5 & 3 & 0 & 36 & 25 & 31 & 1 & 5 & 21 & 46 & 20 & 2 & 4 & 3 \\
\hline $\begin{array}{l}12 \\
12\end{array}$ & 19 & 3 & 11 & $\begin{array}{r}38 \\
36\end{array}$ & $\begin{array}{r}29 \\
\end{array}$ & 0 & 0 & 5 & 3 & 0 & $\begin{array}{r}34 \\
34\end{array}$ & $\begin{array}{r}25 \\
25\end{array}$ & $\begin{array}{l}32 \\
33\end{array}$ & 1 & 5 & $\begin{aligned} 21 \\
20\end{aligned}$ & 45 & 20 & 2 & 4 & 3 \\
\hline $\begin{array}{l}13 \\
14\end{array}$ & $\begin{aligned} 20 \\
20\end{aligned}$ & 3 & 10 & $\begin{array}{l}36 \\
34\end{array}$ & $\begin{array}{r}31 \\
33\end{array}$ & 0 & 0 & 5 & 3 & 0 & $\begin{array}{r}33 \\
33\end{array}$ & $\begin{array}{r}26 \\
26\end{array}$ & $\begin{array}{l}33 \\
34\end{array}$ & 1 & 5 & $\begin{aligned} 20 \\
20\end{aligned}$ & $\begin{array}{l}45 \\
45\end{array}$ & $\begin{array}{l}20 \\
19\end{array}$ & 2 & 4 & 3 \\
\hline $\begin{array}{l}14 \\
15\end{array}$ & $\begin{array}{l}20 \\
21\end{array}$ & $\begin{array}{l}3 \\
3\end{array}$ & $\begin{array}{l}10 \\
10\end{array}$ & $\begin{array}{l}34 \\
32\end{array}$ & $\begin{array}{l}33 \\
34\end{array}$ & $\begin{array}{l}0 \\
0\end{array}$ & $\begin{array}{l}0 \\
0\end{array}$ & $\begin{array}{l}5 \\
5\end{array}$ & $\begin{array}{l}3 \\
3\end{array}$ & $\begin{array}{l}0 \\
0\end{array}$ & $\begin{array}{l}31 \\
30\end{array}$ & $\begin{array}{l}26 \\
27 \\
27\end{array}$ & $\begin{array}{l}34 \\
35\end{array}$ & $\begin{array}{l}1 \\
1\end{array}$ & $\begin{array}{l}5 \\
5\end{array}$ & $\begin{array}{l}20 \\
20\end{array}$ & $\begin{array}{l}45 \\
45\end{array}$ & $\begin{array}{l}19 \\
19\end{array}$ & $\begin{array}{l}3 \\
3\end{array}$ & $\begin{array}{l}4 \\
4\end{array}$ & $\begin{array}{l}3 \\
3\end{array}$ \\
\hline 16 & 21 & 2 & 10 & 31 & 35 & 0 & 0 & 5 & 2 & 0 & 29 & 27 & 36 & 1 & 5 & 20 & 45 & 19 & 4 & 4 & 3 \\
\hline 17 & 21 & 2 & 9 & 30 & 36 & 0 & 0 & 5 & 2 & 0 & 28 & 27 & 36 & 1 & 5 & 20 & 44 & 19 & 4 & 4 & 3 \\
\hline 18 & 22 & 2 & 9 & 29 & 37 & 0 & 0 & 5 & 2 & 0 & 27 & 27 & 37 & 1 & 5 & 20 & 44 & & 5 & 4 & 3 \\
\hline 19 & 22 & 2 & & & & & & 5 & & & & 28 & & 1 & & 20 & 4 & 19 & & 4 & 3 \\
\hline 20 & 2 & 2 & 9 & 27 & $\begin{array}{ll}38 \\
3\end{array}$ & 0 & 0 & 5 & 2 & 0 & 26 & $\begin{array}{l}28 \\
28\end{array}$ & $\begin{array}{r}56 \\
39\end{array}$ & 1 & 5 & 20 & $\begin{array}{l}44 \\
44\end{array}$ & 19 & $\begin{array}{l}0 \\
6\end{array}$ & $\begin{array}{l}4 \\
4\end{array}$ & $\begin{array}{l}3 \\
3\end{array}$ \\
\hline 21 & 23 & 2 & 9 & 27 & 38 & 1 & 0 & 5 & 2 & 0 & 25 & 28 & 39 & 1 & 5 & 20 & 43 & 18 & 7 & 4 & 3 \\
\hline 22 & 24 & 2 & 8 & 26 & 39 & 1 & 0 & 5 & 2 & 0 & 25 & 28 & 40 & 1 & 5 & 19 & 43 & 18 & 7 & 4 & 3 \\
\hline 23 & 24 & 2 & 8 & 26 & 39 & 1 & 0 & 5 & 2 & 0 & 24 & 28 & 40 & 1 & . & 19 & 43 & 18 & 8 & 4 & 3 \\
\hline 24 & 24 & 2 & 8 & 26 & 39 & 1 & 0 & 5 & 2 & 0 & 24 & 28 & 41 & 1 & 5 & 19 & 42 & 18 & 9 & 4 & 3 \\
\hline
\end{tabular}


Table 3

Variance decomposition for the Index of Exchange Market Pressure

During Dual Market Regimes

\begin{tabular}{|c|c|c|c|c|c|c|}
\hline \multirow[b]{2}{*}{$\begin{array}{l}\text { Horizon } \\
\text { (months) }\end{array}$} & \multicolumn{6}{|c|}{ Fraction of Variance Due to Shocks to: } \\
\hline & $\begin{array}{l}\text { Money } \\
\text { Supply }\end{array}$ & $\begin{array}{l}\text { Government } \\
\text { Deficit }\end{array}$ & $\begin{array}{l}\text { Money } \\
\text { Demand }\end{array}$ & $\begin{array}{c}\text { World Real } \\
\text { Interest Rate }\end{array}$ & $\begin{array}{l}\text { Investors' } \\
\text { Interest in } \\
\text { Emerging } \\
\text { Markets }\end{array}$ & $\begin{array}{c}\text { Real } \\
\text { Exchange } \\
\text { Rate * }\end{array}$ \\
\hline 1 & 51 & 0 & 47 & 1 & 0 & 0 \\
\hline 2 & 48 & 3 & 47 & 1 & 1 & 0 \\
\hline 3 & 44 & 7 & 45 & 2 & 2 & 1 \\
\hline 4 & 40 & 10 & 42 & 4 & 2 & 2 \\
\hline 5 & 37 & 12 & 40 & 7 & 3 & 3 \\
\hline 6 & 35 & 13 & 37 & 9 & 3 & 4 \\
\hline 7 & 33 & 13 & 35 & 11 & 3 & 4 \\
\hline 8 & 32 & 13 & 34 & 14 & 4 & 5 \\
\hline 9 & 31 & 12 & 32 & 16 & 4 & 5 \\
\hline 10 & 30 & 12 & 31 & 18 & 4 & 5 \\
\hline 11 & 29 & 11 & 30 & 19 & 4 & 5 \\
\hline 12 & 29 & 11 & 29 & 21 & 5 & 5 \\
\hline 13 & 28 & 11 & 29 & 22 & 5 & 5 \\
\hline 14 & 28 & 11 & 28 & 24 & 5 & 5 \\
\hline 15 & 27 & 11 & 27 & 25 & 5 & 5 \\
\hline 16 & 27 & 11 & 27 & 26 & 5 & 5 \\
\hline 17 & 26 & 11 & 26 & 27 & 5 & 5 \\
\hline 18 & 26 & 11 & 26 & 27 & 5 & 5 \\
\hline 19 & 25 & 11 & 25 & 28 & 5 & 5 \\
\hline 20 & 25 & 11 & 25 & 29 & 5 & 4 \\
\hline 21 & 25 & 11 & 25 & 29 & 6 & 4 \\
\hline 22 & 24 & 12 & 24 & 30 & 6 & 4 \\
\hline 23 & 24 & 12 & 24 & 30 & 6 & 4 \\
\hline 24 & 24 & 12 & 24 & 31 & 6 & 4 \\
\hline
\end{tabular}

Note: * It captures responses to exogenous shocks to the real exchange rate, such as nominal devaluations in trading-partner countries. 
Table 4

The Role of Domestic and External Shocks on the Onset of Crises

\begin{tabular}{|c|c|c|c|c|c|c|c|c|c|}
\hline \multirow[b]{3}{*}{ Crisis } & \multicolumn{9}{|c|}{ Losses of Reserves or Increases in the Dual Market Premium: Percentage Share Explained by: } \\
\hline & \multicolumn{4}{|c|}{ External Shocks } & \multicolumn{5}{|c|}{ Domestic Shocks } \\
\hline & Total & $\begin{array}{l}\text { World Real } \\
\text { Interest Rate }\end{array}$ & $\begin{array}{l}\text { Investors' } \\
\text { Interest in } \\
\text { Emerging } \\
\text { Markets } \\
\end{array}$ & $\begin{array}{c}\text { Real } \\
\text { Exchange } \\
\text { Rate }\end{array}$ & Total & $\begin{array}{l}\text { Money } \\
\text { Supply }\end{array}$ & $\begin{array}{l}\text { Government } \\
\text { Deficit }\end{array}$ & Output & $\begin{array}{c}\text { Money } \\
\text { Demand }\end{array}$ \\
\hline March 1975 & 41 & 34 & -3 & 9 & 59 & 36 & 7 & $\ldots$ & 16 \\
\hline February 1981 and July 1982 & 42 & 53 & -9 & -2 & 58 & 18 & 2 & -3 & 40 \\
\hline September 1987 & 0 & -14 & 6 & 8 & 100 & 23 & -14 & 14 & 77 \\
\hline August 1988 and July 1989 & 41 & 17 & 12 & 12 & 59 & 72 & 2 & $\ldots$ & -16 \\
\hline March 1995 & 93 & 69 & 24 & -1 & 7 & -1 & -3 & -4 & 15 \\
\hline January 2002 & 11 & 22 & -20 & 8 & 91 & 13 & -7 & 63 & 22 \\
\hline
\end{tabular}

Note: This table focuses on explaining the onset of crises. The historical decomposition starts from the month when foreign exchange reserves are at their peak or when the dual market premium is at its through and ends on the month of the crisis. Numbers in bold signify that impulse responses for these shocks are significant for most horizons. 
Table 5

Costs of Crises

(in percent)

\begin{tabular}{|l|c|c|c|c|c|}
\hline \multicolumn{1}{|c|}{ Crisis } & $\begin{array}{c}\text { Reserve losses } \\
\text { in the Six } \\
\text { Months Prior } \\
\text { to the Crisis }\end{array}$ & $\begin{array}{c}\text { Real Exchange } \\
\text { Rate } \\
\text { Depreciation } \\
\text { in the Six } \\
\text { Months } \\
\text { Following the } \\
\text { Crisis }\end{array}$ & $\begin{array}{c}\text { Output } \\
\text { Changes in } \\
\text { the Year of } \\
\text { the Crisis and } \\
\text { the Following } \\
\text { Year }\end{array}$ & $\begin{array}{c}\text { Exports } \\
\text { Changes in } \\
\text { the Year } \\
\text { Following the } \\
\text { Crisis }\end{array}$ & $\begin{array}{c}\text { Import } \\
\text { Changes in } \\
\text { the Year } \\
\text { Following the } \\
\text { Crisis }\end{array}$ \\
\hline March 1975 & 40 & 181 & -5 & 20 & -46 \\
February 1981 & 56 & 53 & -5 & 30 & -50 \\
July 1982 & 10 & 30 & -8 & 19 & -6 \\
September 1987 & 36 & 27 & 1 & 34 & -4 \\
August 1988 & 47 & 66 & -8 & 35 & -39 \\
July 1989 & 20 & -20 & 9 & 6 & 4 \\
March 1995 & 16 & 5 & 3 & 35 & 10 \\
January 2002 & 25 & 174 & -15 & 4 & -16 \\
Crises with Domestic Vulnerabilities & 33 & 73 & -5 & 21 & -23 \\
Crises with External Adverse Shocks & 16 & 5 & 3 & 35 & 10 \\
\hline
\end{tabular}

Notes: Reserves, exports, and imports are in U.S. dollars. Output is measured as real GDP. The last two rows of the Table show the average costs of currency crises mainly triggered by domestic vulnerabilities and currency crises mainly fueled by adverse external shocks. As discussed in the paper, the only crisis triggered by external adverse shocks is the March 1995 crisis. 
Figure 1

Indicators of the Fragility Buildup

Foreign Exchange Reserves

(in Billion Dollars)

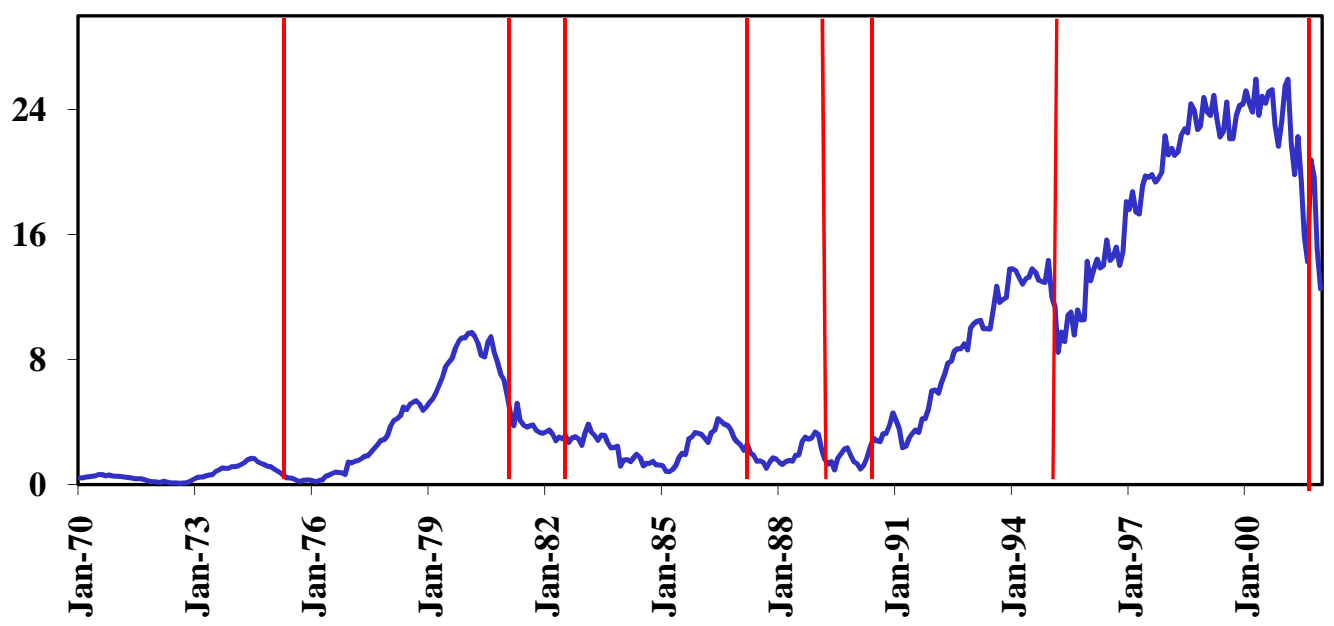

Dual Exchange Market Premium

(in Percent)

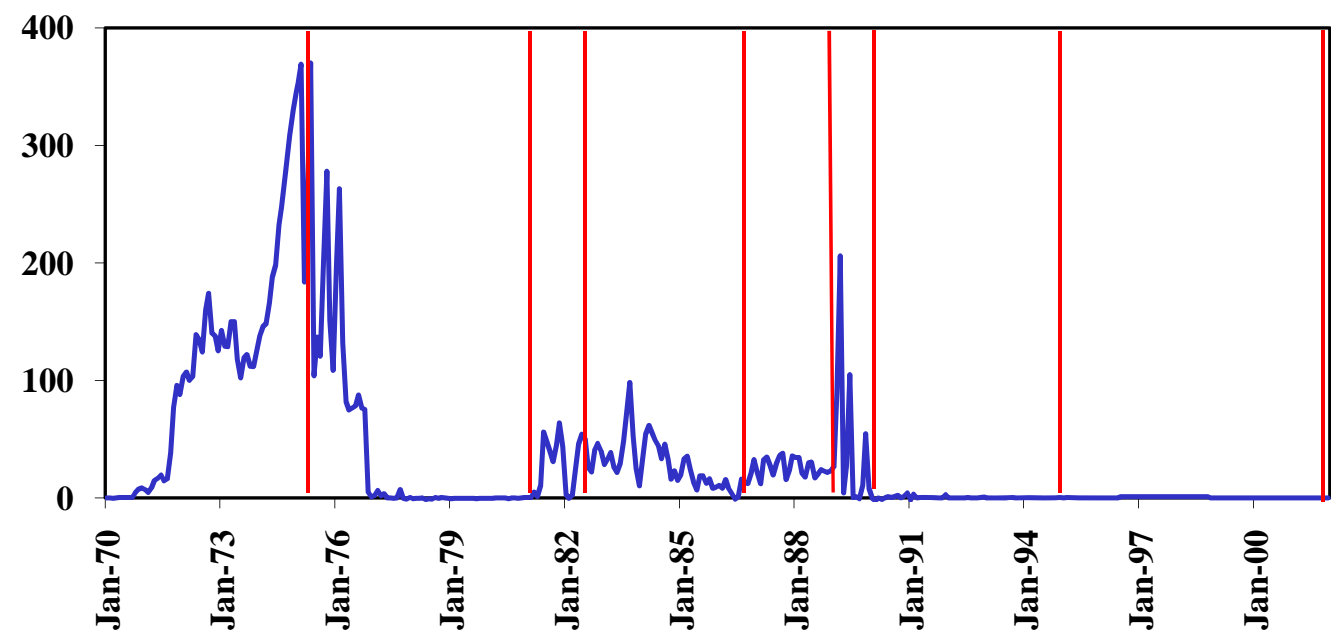

Note: The vertical lines indicate the month of the crises. 
Figure 2

Domestic and External Indicators

Domestic Credit

(in Billion Dollars)

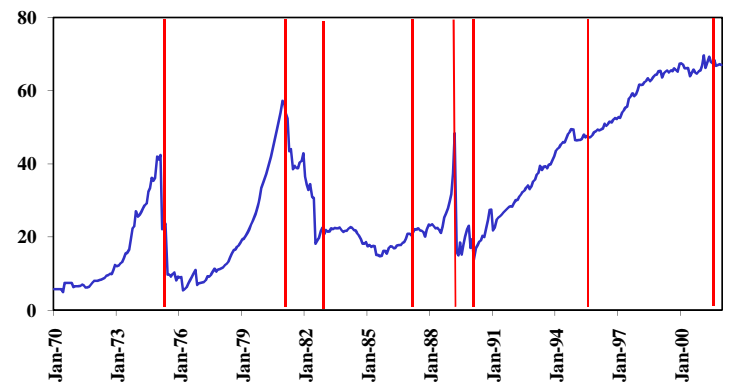

Real Exchange Rate Index Number

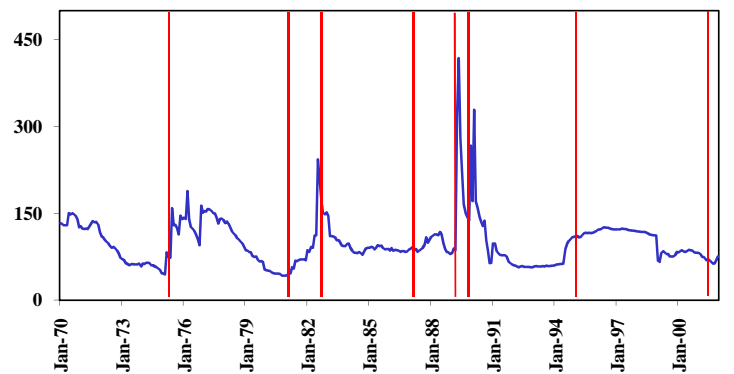

World Real Interest Rate

(Percent per Annum)

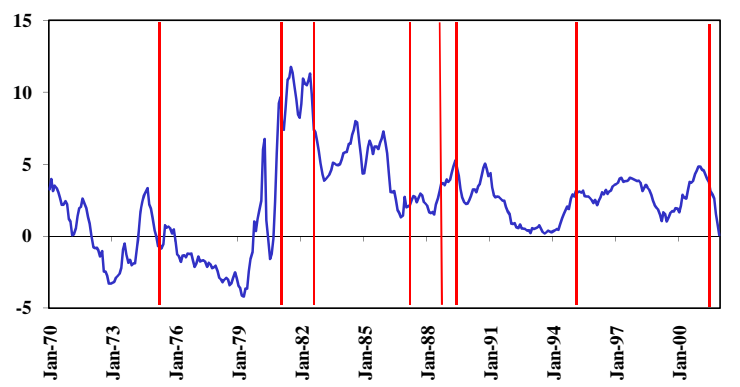

Government Deficit (Percent of GDP)

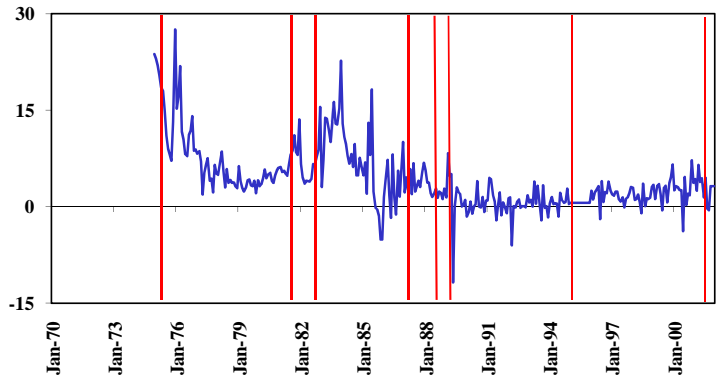

Industrial Production Index Number

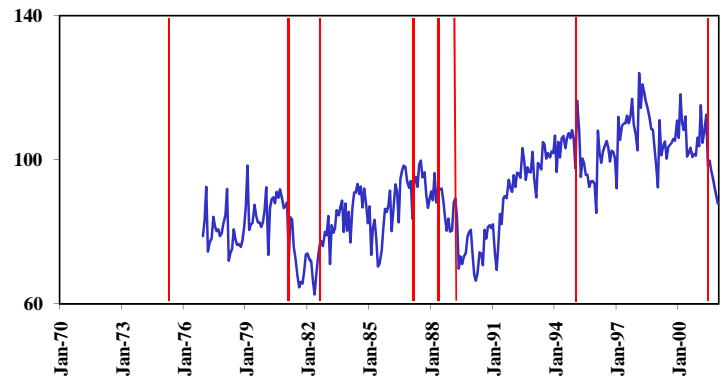

Latin American Foreign Exchange Reserves: First Principal Component Index Number

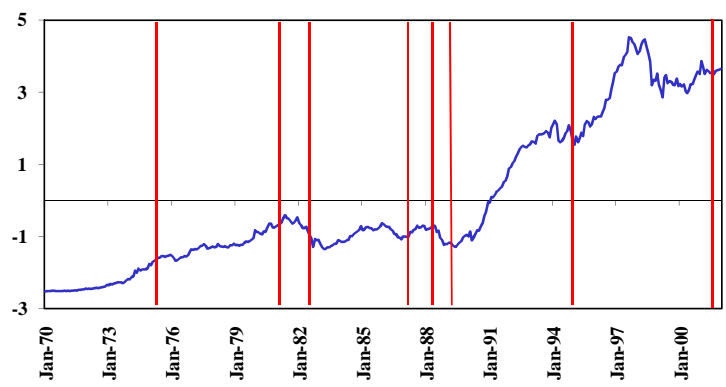


Figure 3
Impulse Responses of Foreign Exchange Reserves to Various Shocks during Fixed Exchange Rate Regimes

Tablita, Alemann, and Austral Plans

Money Supply

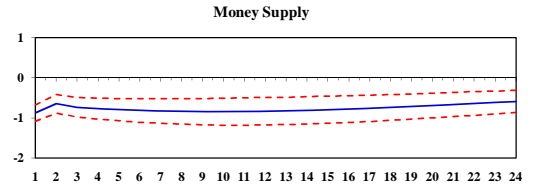

Government Defici

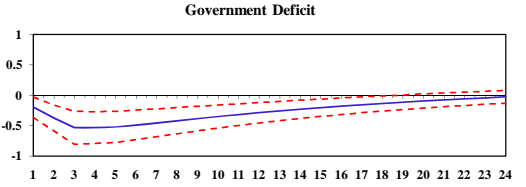

Output

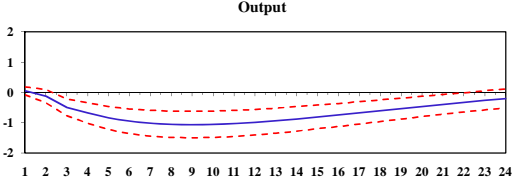

Money Demand

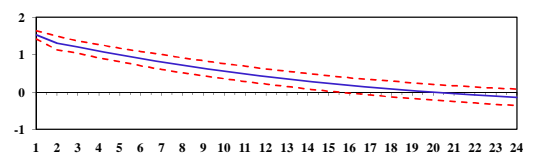

World Real Interest Rate

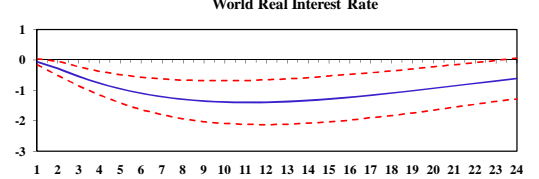

Investors' Interest in Emerging Markets

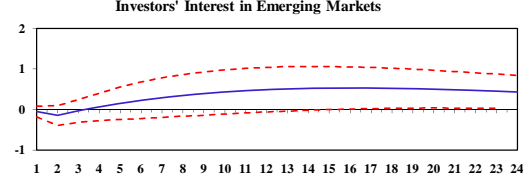

Real Exchange Rate

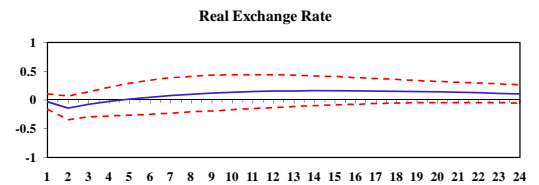

Convertibility Plan: April 1991-December 1998

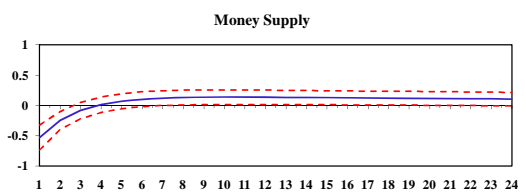

Government Deficit

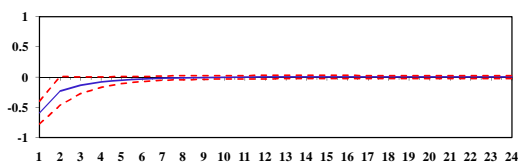

Output

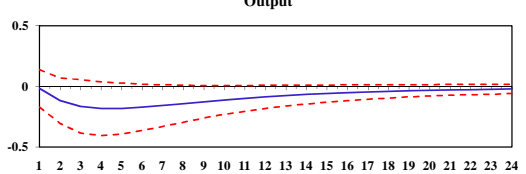

Money Demand

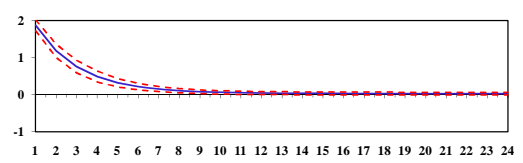

World Real Interest Rate

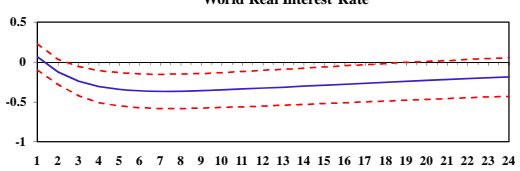

Investors' Interest in Emerging Markets

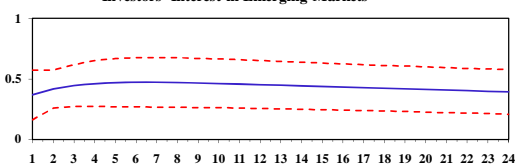

Real Exchange Rate

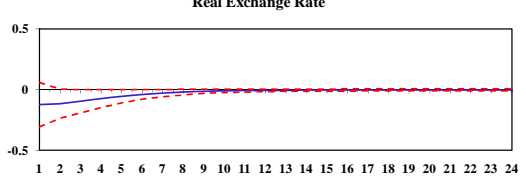

Convertibility Plan: January1999-January 2002

Money Supply

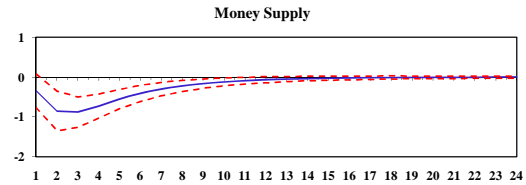

Government Deficit

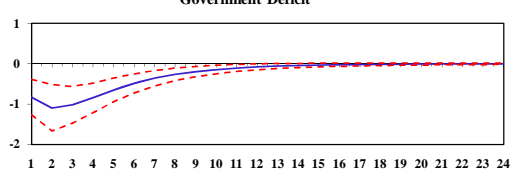

Output

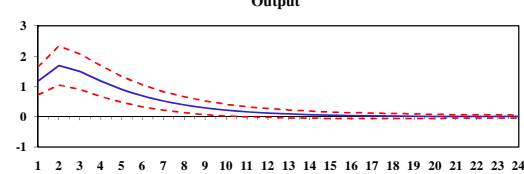

Money Demand

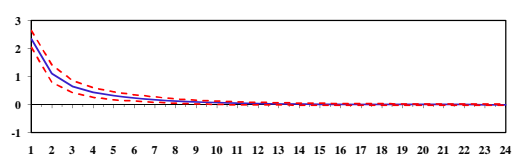

World Real Interest Rate

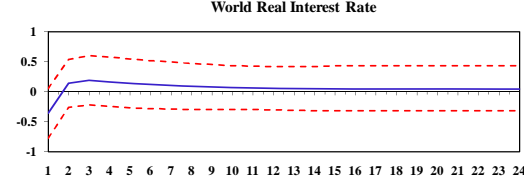

Investors' Interest in Emerging Markets

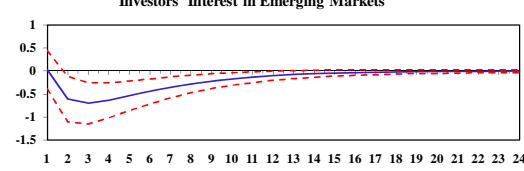

Real Exchange Rate

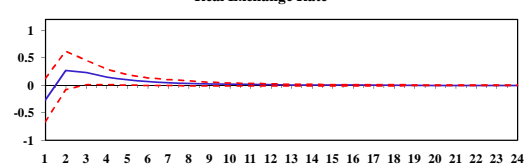


Figure 4

Impulse Response of the Index of Market Pressure to Various Shocks during Dual Exchange Regimes

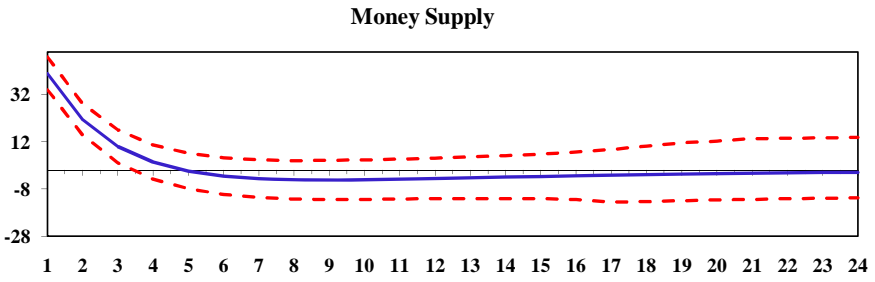

Government Deficit

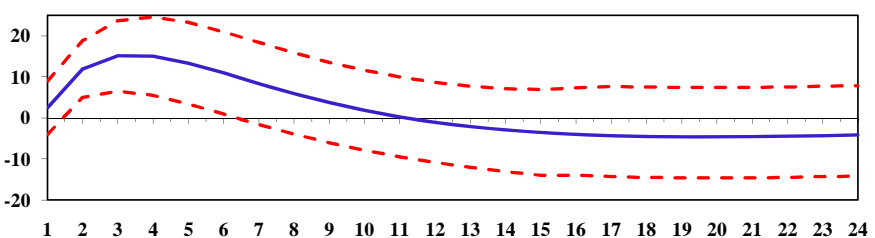

Money Demand

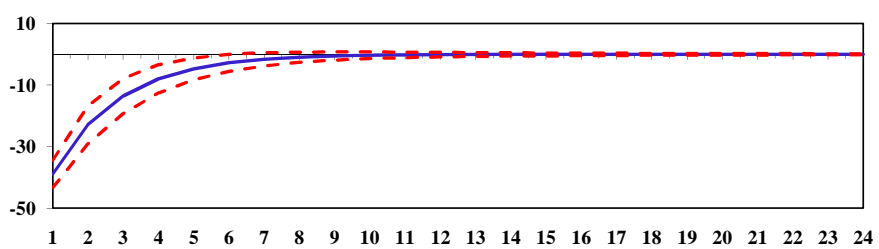

World Real Interest Rate

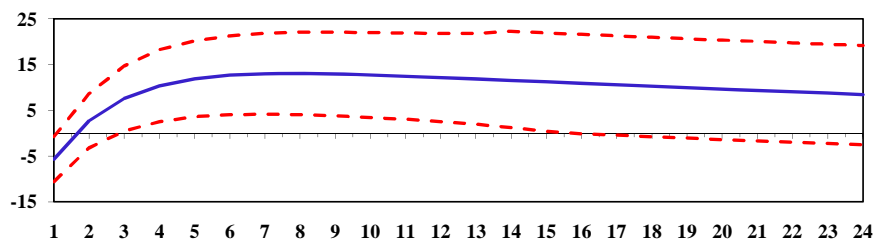

Investors' Interest in Emerging Markets

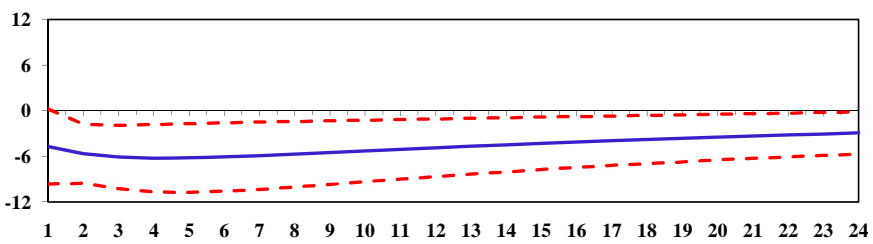

Real Exchange Rate

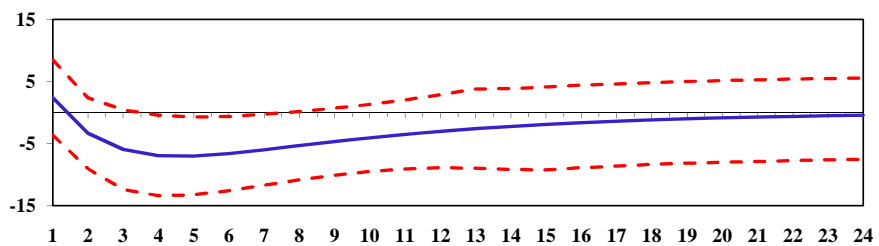


Figure 5

Sources of the Fluctuations in Foreign Exchange Reserves

During Fixed Exchange Rate Regimes

Tablita and Alemann Plans
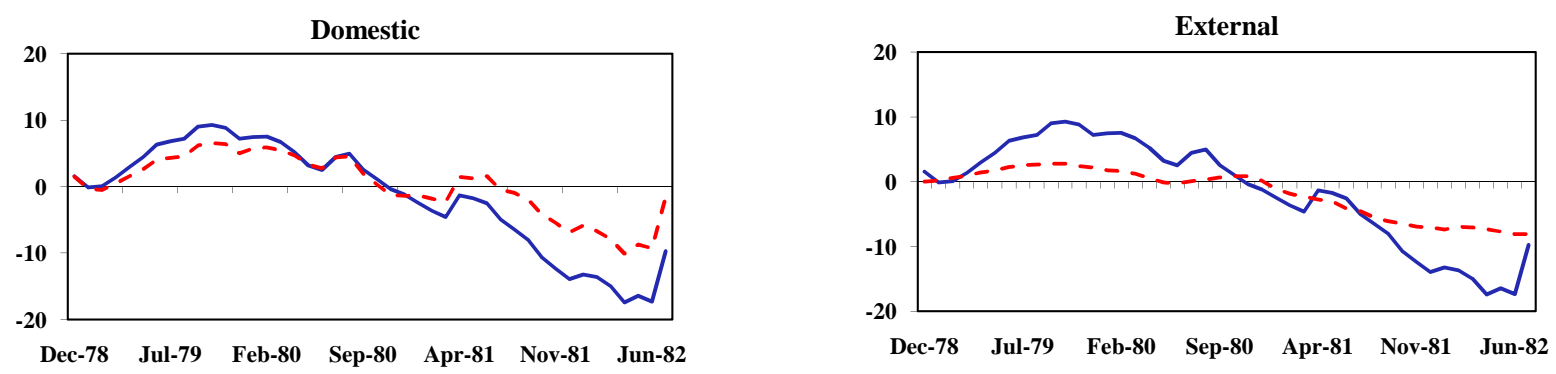

\section{Austral Plan}
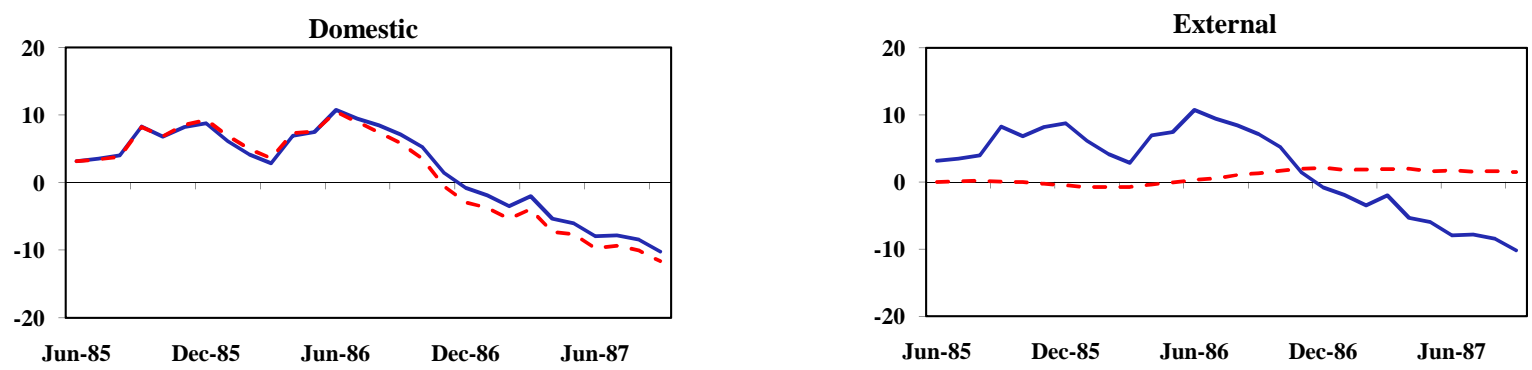

Convertibility Plan: April 1991-December 1998
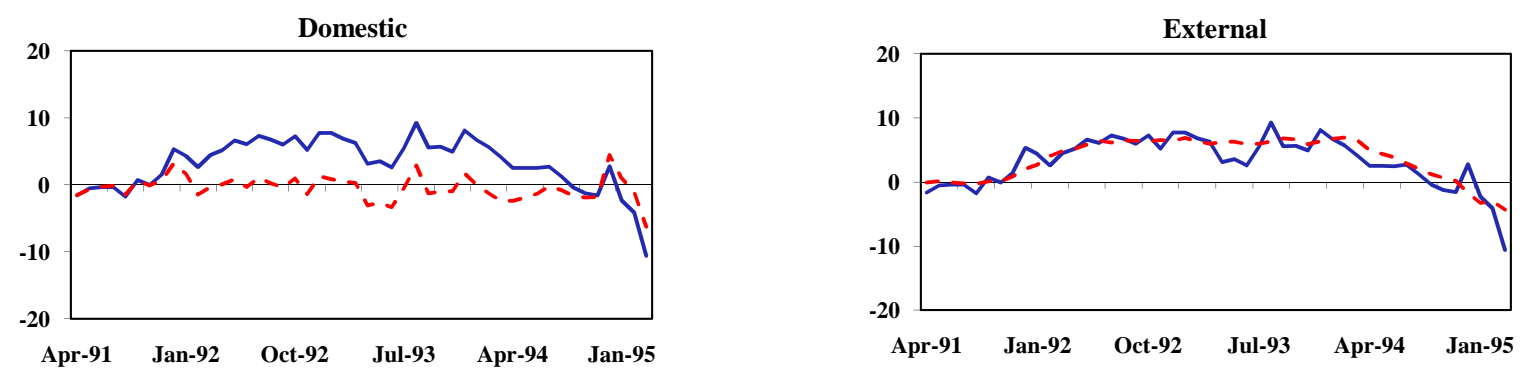

Convertibility Plan: January 1999-January 2002
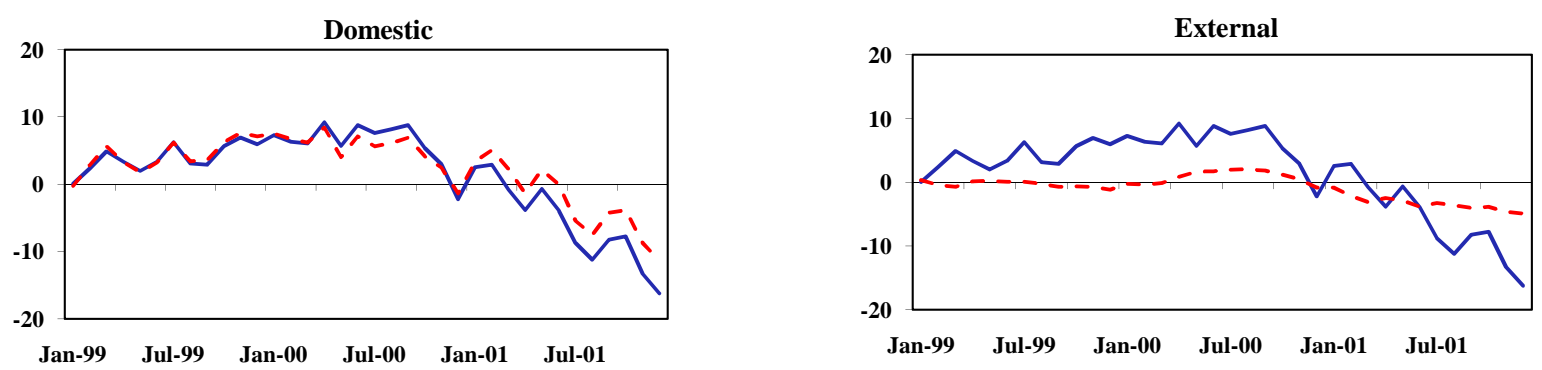

Note: In each panel, the solid line shows the difference between the level of reserves (as a share of domestic credit in dollars--in percent) and the level that would have been forecasted based upon the history of the system up through the implementation of the stabilization plan. Thus, it reflects the cumulative impact of both domestic and foreign shocks. The dotted line shows the actual path of reserves that would have prevailed if either domestic or foreign shocks had hit the system. 
Figure 6

Sources of Fluctuations in the Index of Market Pressure During Dual Exchange Rate Regimes

\section{Gelbard Plan}
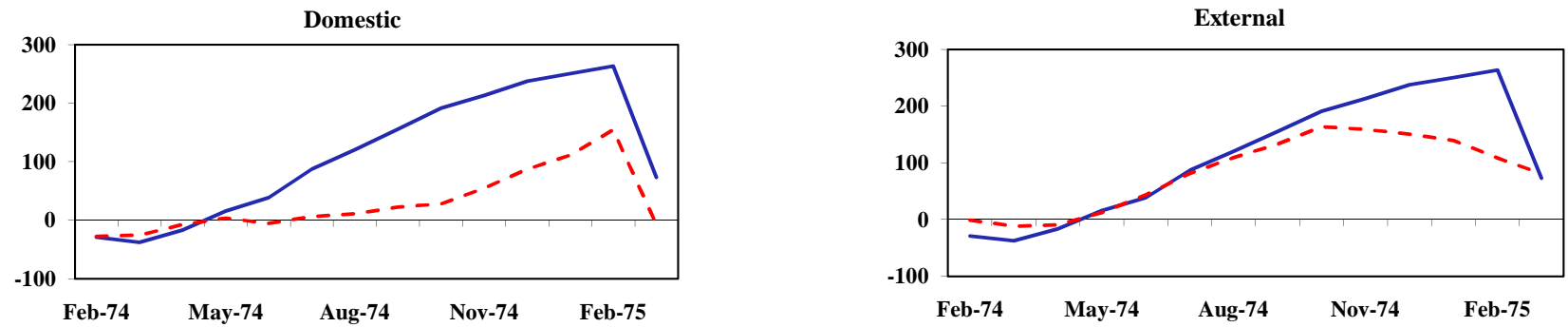

Primavera and BB Plans

Domestic

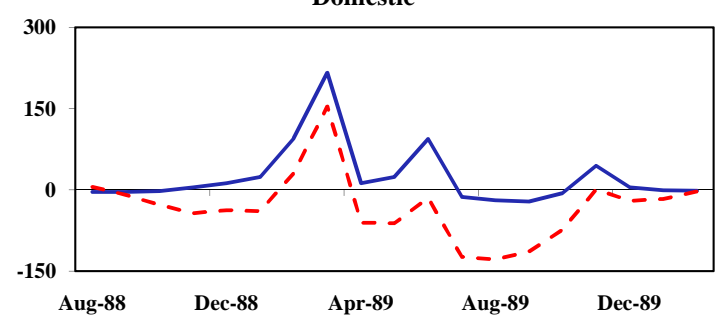

External

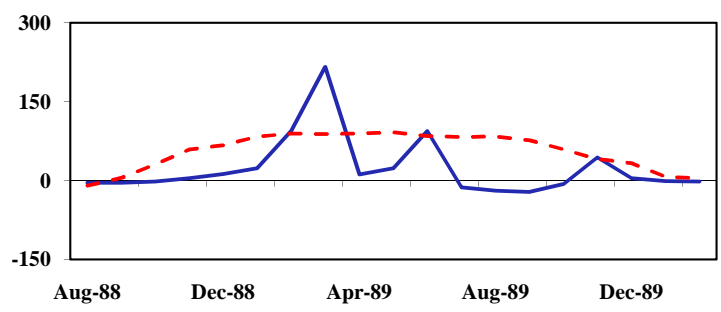

Note: In each panel, the solid line shows the difference between the level of the index of exchange market pressure (in percent) and the level that would have been forecasted based upon the history of the system up through the implementation of the stabilization plan. Thus, it reflects the cumulative impact of both domestic and foreign shocks. The dotted line shows the actual path of the index of exchange market pressure that would have prevailed if either domestic or foreign shocks had hit the system. 